University of Rhode Island

DigitalCommons@URI

Open Access Master's Theses

1991

\title{
FLUORESCENCE POLARIZATION IMMUNOASSAY OF VITREOUS HUMOR TO DETECT DRUG USE
}

Nancy Round Haley

University of Rhode Island

Follow this and additional works at: https://digitalcommons.uri.edu/theses

\section{Recommended Citation}

Haley, Nancy Round, "FLUORESCENCE POLARIZATION IMMUNOASSAY OF VITREOUS HUMOR TO DETECT DRUG USE" (1991). Open Access Master's Theses. Paper 256.

https://digitalcommons.uri.edu/theses/256

This Thesis is brought to you for free and open access by DigitalCommons@URI. It has been accepted for inclusion in Open Access Master's Theses by an authorized administrator of DigitalCommons@URI. For more information, please contact digitalcommons-group@uri.edu. 


\title{
FLUORESCENCE POLARIZATION IMMUNOASSAY OF VITREOUS HUMOR TO DETECT DRUG USE \\ BY \\ NANCY ROUND HALEY
}

\author{
A THESIS SUBMITTED IN PARTIAL FULFILLMENT \\ OF THE REQUIREMENTS FOR THE DEGREE OF \\ MASTER OF SCIENCE \\ IN \\ PHARMACOLOGY AND TOXICOLOGY
}

\author{
UNIVERSITY OF RHODE ISLAND \\ 1991
}


MASTER OF SCIENCE THESIS

OF

NANCY ROUND HALEY

APPROVED:

Thesis Committee Major Professor
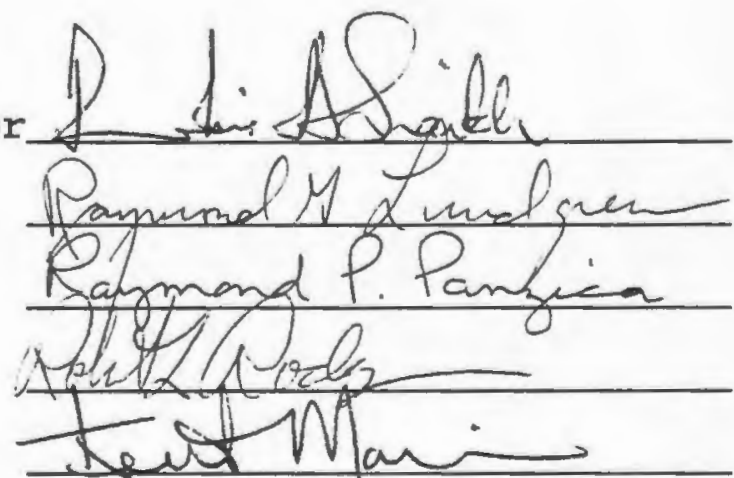

DEAN OF THE GRADUATE SCHOOL

UNIVERSITY OF RHODE ISIAND 


\section{ABSTRACT}

In recent years the number of postmortem cases in which cocaine involvement is suspected has increased considerably. This has created a need for a rapid screening procedure for the postmortem samples. The present study examined the usefulness of vitreous humor specimens, analyzed by a rapid immunological assay, as a possible alternative to the more conventional and relatively slow gas chromatography/mass spectrometry of blood samples to screen for antemortem cocaine use.

Medical examiner cases occurring over a six month period were reviewed and forty-eight cases which were determined to be drug related or drug induced deaths were analyzed. Postmortem concentrations of cocaine and its hydrolysis product, benzoylecgonine, recovered from blood, were compared to the concentrations detected in vitreous humor. These specimens were screened via a rapid fluorescence polarization immunoassay (FPIA) and also analyzed by gas chromatography/ mass spectrometry (GC/MS) for a quantitation of cocaine and its primary hydrolysis product, benzoylecgonine.

An assessment of FPIA to screen postmortem vitreous humor samples was carried out. The sensitivity of this method was $0.03 \mathrm{mcg} / \mathrm{ml}$. The vitreous humor cocaine metabolite levels by FPIA and GC/MS demonstrated a correlation coefficient of 0.7 . Blood and vitreous humor benzoylecgonine levels from the same postmortem case analyzed by GC/MS showed a correlation coef- 
ficient of 0.5 .

Significant correlation of the FPIA results with the GC/MS results demonstrate that the FPIA analysis of vitreous humor samples appears to be a valid screening technique to detect antemortem cocaine use. The vitreous humor was found to be a clean and stable body fluid which was suitable for this technique. It is concluded that the screening of postmortem vitreous humor for cocaine use by this FPIA method is a useful and reliable screening technique in forensic toxicology. 


\section{ACKNOWLEDGEMENTS}

The author first wishes to dedicate this thesis to the memory of Dr. David R. DeFanti. Having been the major professor and advisor to the author from 1986 until his death in February, 1991, Dr. DeFanti gave invaluable assistance throughout the author's years of graduate study. For being a mentor, and for his concern and patience, the author expresses her sincere appreciation.

The author wishes to thank Dr. Raymond G. Lundgren and Dr. David B. Uliss for allowing her to utilize the equipment and materials at the Forensic Sciences Section of the Division of Laboratories to complete this study.

The author wishes to thank william Q. Sturner, M.D., former Chief Medical Examiner of Rhode Island for granting permission and providing postmortem samples to be used in this research.

The author wishes to sincerely thank the members of her committee, Dr. Zahir Shaikh, Dr. Raymond P. Panzica, Dr. John R. Babson and Dr. Raymond G. Lundgren for their participation and encouragement.

The author wishes to thank her co-workers at the Forensic Toxicology Laboratory for their advice and moral support in this investigative study. 
The author especially wishes to express her gratefulness to her husband and daughters for their understanding and love throughout this thesis research and her whole graduate career. The author wishes to thank Abbott Laboratories for generously supplying all immunoassay reagents needed for this study.

The author would like to thank the society of Forensic Toxicologists for the Educational Research Award and the American Academy of Forensic Sciences for the Toxicology Scholarship Award which helped to fund this project. 
TABLE OF CONTENTS

Page

ABSTRACT. .................................

ACKNOWLEDGEMENTS ............................ iv

TABLE OF CONTENTS...............................

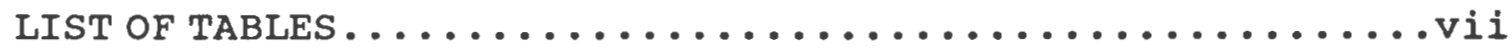

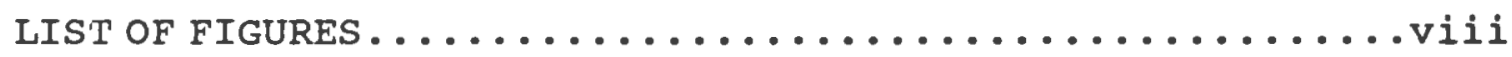

I. INTRODUCTION.........................

II. LITERATURE REVIEW.......................

III. EXPERIMENTAL....................... 16

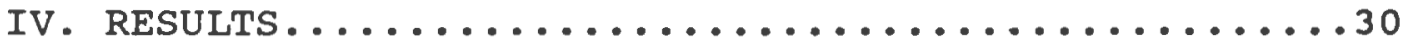

v. DISCUSSION........................... 45

VI. SUMMARY AND CONCLUSIONS.................49

VII. APPENDICES......................... 51

VIII. BIBLIOGRAPHY......................66 


\section{LIST OF TABLES}

Table

Page

1. Comparison of Three Postmortem Body Fluids......4

2. FPIA Cocaine Metabolites Assay Sensitivity and

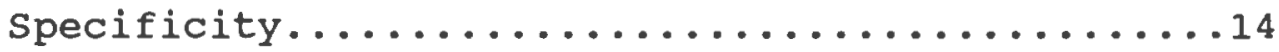

3. GC/MS Quantitation Report showing Retention times, Ion Abundance and Calculated Concentrations....29

4. Medical Examiner Cases with Vitreous Humor Samples Analyzed for Cocaine Metabolites.............31

5. Data showing Vitreous Humor Sample I.D.\#, FPIA reading, and GC/MS Benzoylecgonine Quantitation..33

6. Linear Regression Analysis of Vitreous Humor FPIA vs. GC/MS Benzoylecgonine Levels................34

7. Data showing Vitreous Humor Benzoylecgonine Levels by GC/MS and Blood Benzoylecgonine Levels by GC/MS

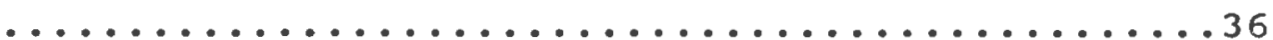

8. Linear Regression Analysis of Vitreous Humor Benzoylecgonine Levels by GC/MS and Blood Benzoyl-

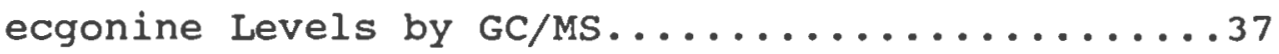

9. Summary of Analyses of Data from Vitreous Humors

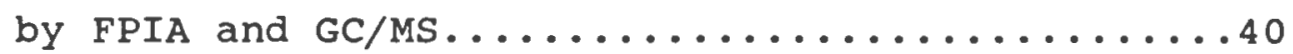

10. Accuracy Check with Diagnostics Products Corp.



11. Precision study of pooled Vitreous Humor samplesuntreated and treated with $10 \%$ Trichloroacetic

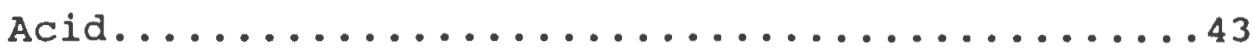




\section{LIST OF FIGURES}

Figure

Page

1. Cocaine Metabolism showing Formation

of Metabolites......................8

2. FPIA Calibration Curve demonstrating Inverse Relationship between Polarization and concen-

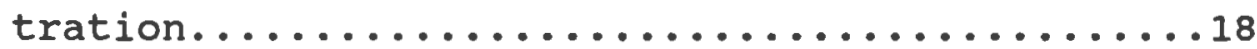

3. Mass Spectra of Benzoylecgonine and Benzoylecgo-

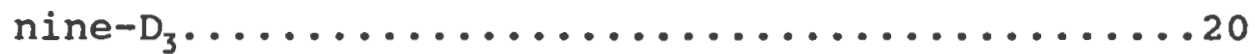

4. Mass spectra of Cocaine and Cocaine- $D_{3} \ldots \ldots \ldots 21$

5. Total Ion Chromatogram (TIC) of Extracted Vitreous

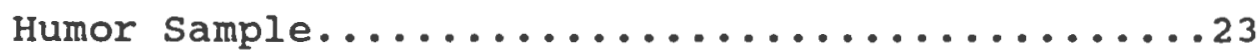

6. Reaction for the Derivatization of Benzoylecgo-

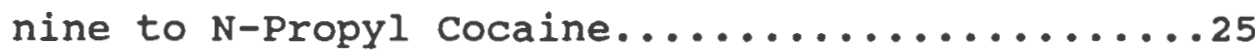

7. Calibration Curve of Cocaine by GC/MS........26

8. Calibration Curve of Benzoylecgonine by GC/MS...

9. Scatter plot of Vitreous Humor Levels by FPIA

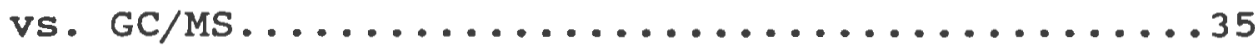

10. Scatter plot of Vitreous Humor and Blood Benzoylecgonine Levels by GC/MS......................... 


\section{INTRODUCTION}

Forensic toxicology is the study of poison isolation, identification, and quantitation from biological specimens for legal purposes. Most drug analyses in forensic toxicology are performed on urine, blood, or other tissue. During the multistep drug extraction processes, the samples are susceptible to emulsification and pipetting errors. Blood samples are also degraded by postmortem changes. The combination of all these factors may result in loss of sensitivity and poor reproducibility in an assay.

Another postmortem fluid which is readily available but is often ignored is vitreous humor. In comparison with blood and urine, it is not as susceptible to major postmortem changes. The vitreous is compartmentalized and isolated, which makes it a suitable toxicological material, even after embalming or putrefaction, when blood may be unavailable (Coe, and Sherman, 1970).

This study investigated three main areas relating to fluorescence polarization immunoassay (FPIA) technology on vitreous humor specimens in determining drug use prior to death. First, the data generated was used to determine if elevated levels of cocaine and/or metabolites in blood are accompanied by elevated levels in vitreous humor. Secondly, this information coupled with the time between drug use and death (if available) might allow a calculation as to how 
rapidly cocaine and/or metabolites diffuse into vitreous humor specimens (Jones and Pounder, 1987). And lastly, this research further demonstrated that FPIA screening of vitreous humor specimens is valid in forensic toxicology. 


\section{LITERATURE REVIEW}

Vitreous humor is the fluid material which fills the posterior cavity of the eye. It is present at a volume of 2 to 2.5 milliliters in each eye (Logan and stafford, 1989). The vitreous (hyaloid body) occupies about $80 \%$ of the volume of the ocular globe. It provides structural support and maintains intraocular pressure.

Chemically, the vitreous humor is a mucopolysaccharide gel composed of hyaluronic acid and collagen, and it has a water content of between 98 and $99.7 \%$ (Table 1). This table shows the relative simplicity and stability of vitreous humor. Vitreous humor is a clean bilogical fluid containing less protein than urine, and it can be collected with ease. In the forensic domain, the primary use of vitreous humor to date has been to aid in the postmortem diagnosis of disease, the analysis of electrolyte composition and enzymatic activity to determine "time-since-death" determinations (Devgun and Dunbar, 1986).

Vitreous is a partitioned fluid; but the amount of water movement is very high $(\mathrm{T} 1 / 2=10-15$ minutes $)$. This tends to make one expect that drug levels might be expected to show good correlation with corresponding blood levels. This is true of ethanol determinations and vitreous humor samples which are often analyzed postmortem for alcohol concentration. The mean ratio of vitreous humor to blood ethanol concentration is 1.17 (Caplan and Levine, 1990). 
Table 1. Comparison of the Composition of Three Postmortem Body Fluids

\begin{tabular}{|c|c|c|}
\hline $\begin{array}{l}\text { Putrified Blood } \\
\text { (pH 4-9) }\end{array}$ & $\begin{array}{l}\text { Urine } \\
\text { (pH 4-9) }\end{array}$ & $\begin{array}{l}\text { Vitreous Humor } \\
\text { (pH } 7-7.8)\end{array}$ \\
\hline $\begin{array}{l}\text { Water }(20-70 \%) \\
\text { Few cellstdebris } \\
\text { Lysate } \\
\text { Clots } \\
\text { Denatured clots } \\
\text { Bacterial debris } \\
\text { Denatured protein } \\
\text { Fat droplets } \\
\text { Steroids } \\
\text { Putrefactive base } \\
\text { Protein microagglu } \\
\text { Enzymes }\end{array}$ & $\begin{array}{l}\text { Water (96-99.9\%) } \\
\text { Glucose } \\
\text { Protein } \\
\text { Ammonia } \\
\text { Creatinine } \\
\text { Urea } \\
\text { Uric acid } \\
\text { Steroids } \\
\text { Pigments } \\
\text { Amino Acids } \\
\text { ates }\end{array}$ & $\begin{array}{l}\text { Water }(98-99.7 \%) \\
\text { Glucose } \\
\text { Hyaluronic Acid } \\
\text { Anions/cations } \\
\text { Collagen }\end{array}$ \\
\hline
\end{tabular}


The use of vitreous humor for toxicological analysis was first published involving ethanol determinations (Sturner and Coumbis, 1966). In this publication the vitreous humor ethanol levels were compared to blood ethanol levels, obtained simultaneously at autopsy. There have been various reports subsequent to this, verifying the usefulness and accuracy of this approach (Coe and Sherman, 1970, Felby and Olsen, 1969, Ziminski et.al., 1984).

In the literature, various drug distributions studies do mention vitreous drug levels, but little is said about the relation of these levels to blood levels or their ultimate interpretation. A study on alcohol levels illustrated that when patients have long survival times, they reveal blood/ vitreous values approaching unity (Sturner and Garriot, 1975). There is speculation that the ratios reached at equilibrium depend on the drug's lipid solubility, plasma protein binding, and solubility in vitreous humor.

The substances that have been studied include such drugs as barbiturates, meprobamate, salicylates, ethchlorvynol, digoxin, quinine, and lithium (Felby and Olsen, 1969). Other studies have also appeared that relate levels of such drugs as barbiturates, methadone and morphine in vitreous humor to other tissues and fluids (ziminski et. al., 1984). Quantitative postmortem determinations of vitreous drug levels have been reported rather sporadically in the literature.

The physical properties of vitreous humor make it a very good sample material for initial drug screening in postmortem 
cases. Active transport of some compounds into the eye has been observed in some cases. This has been observed in some tests conducted on rabbit eyes with delta-9-tetrahydrocannabinol transport (Sorensen, 1971). Most compounds are believed to enter the eye through passive diffusion, a process limited by their lipophilicity and their charge at physio$\operatorname{logical} \mathrm{pH}$.

There are many advantages to postmortem toxicological analysis of vitreous humor. In most cases, the specimen is easily obtainable at autopsy and obtainable without the necessity of an autopsy. Vitreous humor is often the best or only sample available; especially in cases of severe burning, when the body has been embalmed, in cases of advanced decomposition, and in cases of severe trauma. Vitreous is a clear, serous specimen and it is easy to work with analytically. It is also found in an isolated anatomical position. In addition, the lack of any metabolic activity in the eye suggests that vitreous levels might give a more accurate indication of drug concentrations present in the body at the time of death. Therefore, in the absence of a valid blood specimen, the vitreous humor specimen may permit toxicological interpretation. However, there must be a wealth of data available relating vitreous levels to blood levels before such interpretation would be possible.

The pharmacokinetics of any drug deals with the study of the time course of the drug and its metabolites in the body following administration. Every drug is subject to the 
pharmacokinetic variables of absorption, distribution, metabolism, and excretion. The determination of the drug plasma levels is highly individual and depends upon these variables.

In the human body, the drug, cocaine, is rapidly metabolized ( $1 / 2=0.7$ to 1.5 hours) to ecgonine methyl ester, ecgonine and other fragments by serum cholinesterase and liver esterases (Baselt and Cravey, 1989). Cocaine is broken down to benzoylecgonine by chemical hydrolysis (Figure 1). These processes probably continue postmortem in the blood, liver and in drawn blood "in vitro". Enzymatic breakdown can be inhibited by any number of enzyme inhibitors, including fluoride, organophosphate pesticides, physostigmine, and heavy metals. Hydrolysis can also be slowed by refrigeration or freezing and by decreasing the $\mathrm{pH}$ of the sample below neutral. Refrigeration retards both processes, while freezing blood samples containing sodium fluoride can preserve the cocaine for extended periods of time.

One would expect cocaine in the blood to hydrolyze extensively between the time of death and the time when the autopsy blood specimens are taken. If survival time from dosage exceeds 48 hours, it would most likely result in a negative result, based on the elimination kinetics of the principal cocaine metabolite, benzoylecgonine. The mean urinary elimination half-life of benzoylecgonine has been estimated to be 4.5 hours (range, 2.8 to 10.5 hours) (Ambre et. al., 1988). Elimination rates are dependent, in part, on 
8.



Fig. 1. Cocaine Metabolism showing Formation of Metabolites 
dosage, as well as other factors. Ambre in 1985 devised a nomogram based on published kinetic studies. Assuming a urinary output of $1 \mathrm{ml} / \mathrm{min}$, this nomogram would predict that at least $0.35 \mathrm{mg} / \mathrm{L}$ or $0.35 \mathrm{mcg} / \mathrm{ml}$ of benzoylecgonine should be detectable in the urine for up to 48 hours following a $100 \mathrm{mg}$ or greater dose. These and other studies suggest that little metabolite would be detectable in urine by a homogeneous enzyme immunoassay with a detection limit of $0.30 \mathrm{mcg} / \mathrm{ml}$ beyond 48 hours from the last cocaine dose of $100 \mathrm{mg}$.

In one review of the cocaine Iiterature, it was evident that death from cocaine is rapid and unpredictable (Smart and Anglin, 1987). None of the papers examined were able to illustrate how to translate postmortem values into actual doses taken. Many of the authors state that following an overdose of cocaine, death is astonishingly rapid (Welti and Fishbain, 1985, Welti and Wright, 1979, Mittleman and Welti, 1984). Thus, it may not yet be possible to state the lethal dose of cocaine with any degree of certainty.

It has been suggested that brain tissue may be the better sample for cocaine determination rather than postmortem blood or liver tissue (Sphiehler and Reed, 1985). Cocaine is known to enter and leave the brain rapidly. Some researchers feel that there is an active transport of cocaine into the brain tissue, rather than a passive diffusion. At peak plasma concentrations, the brain cocaine concentration is just over four times the plasma or serum concentration. This brain/blood ratio is the most frequent median found for 
cocaine in cocaine overdose fatalities. As blood cocaine concentrations fall slightly more rapidly than brain tissue concentrations, the brain/blood ratio increases. This increase reaches a peak of approximately 10 (range 8 to 12) between one and two hours after cocaine administration. These authors recommend brain tissue for cocaine determinations over postmortem blood or liver tissue. Brain is a better matrix than blood for cocaine analysis because the parent drug is more stable in the brain's lipid-rich environment. However, the technical difficulties in getting the tissue prepared for analysis may outweigh the accuracy of the brain tissue for cocaine concentration.

The examination of three human brains in the study by Browne, illustrated that cocaine and benzoylecgonine appear to be distributed throughout the different regions of the organ (Browne et al., 1991). This was in agreement with the findings of an earlier study by spiehler and Reed (Spiehler and Reed, 1985). The concentrations of cocaine found in the brain were generally four to eight times greater than that found in blood. The addition of this study to the archives further suggests that brain tissue is a better sample than either blood or liver for cocaine determinations. However, working with brain tissue is difficult, as stated earlier. The presence in the brain of large concentrations of fats and other endogenous materials, make use of this specimen difficult. This material necessitates the use of lengthy and laborious extraction procedures. 
One paper in the literature demonstrated the usefulness of testing decomposed human remains for cocaine in all cases where the presence is suspected (Manhoff et. al., 1991). Cocaine is generally quite labile and has a plasma half-life of less than one hour. It is known that in vivo it is rapidly hydrolyzed by enzymatic and nonenzymatic reactions. Despite this, it has been found that cocaine and its metabolites are frequently detectable in decomposed human remains. Cocaine has been detected even in advanced cases of decomposition and mummification.

Recent data now suggests that blood cocaine concentrations change significantly during the interval between death and autopsy. The change appears to be dependent upon the site from which the blood is sampled. Cocaine concentrations in the heart, aorta, and femoral vein blood increase during the interval between death and autopsy, while the subclavian vein blood decreases (Hearn et. al., 1991). This study emphasizes the difficulty in attempting to estimate the perimortem concentration of cocaine in the blood from any postmortem data. The data implies that cocaine accumulates in some tissues, such as the brain and the liver, and these demonstrate higher cocaine concentrations than in the blood.

In another study where the two eyes were sampled at different postmortem intervals, markedly different cocaine levels were demonstrated (Beno and Kriewall, 1989). In this study also, postmortem release is the only reasonable explanation for this unusual finding. In a case study of 
cocaine involved in a fatal poisoning, cocaine tissue concentrations and body fluid concentrations were reported in the literature for this case (Poklis et. al., 1985). The blood level of cocaine was $1.8 \mathrm{mcg} / \mathrm{ml}$ and vitreous humor level was $2.4 \mathrm{mcg} / \mathrm{ml}$. The blood/vitreous ratio in this case for the parent drug cocaine was 0.75 . There was no benzoylecgonine levels reported in this case report as the procedure used did not analyze for benzoylecgonine. The survival time was known to be less than 2 hours and the drug was intravenously administered.

The incidence of cocaine abuse has arisen dramatically over recent years. This has directly resulted in a major increase in deaths attributed to cocaine overdose as well as to increased findings of cocaine during the screening of biological samples for drugs of abuse. There are numerous methods in the literature describing the analysis of cocaine and its hydrolysis product, benzoylecgonine in body fluids, using high performance liquid chromatography (HPLC) and gas chromatography/mass spectrometry (GC/MS) (Chinn et. al., 1980, Evans and Morarity, 1980, Griesmer et. al., 1983, Logan and Stafford, 1989, Tebbett and McCartney, 1988). All of these methods require that the drugs be first extracted from the biological matrix prior to chromatographic analysis.

Extraction of cocaine and benzoylecgonine is generally by liquid-liquid extraction procedures. Liquid-liquid extraction normally involves the use of volumes of solvents, numerous centrifugation, back extraction and evaporation steps before 
the sample is suitable for analysis. Such methods can provide clean extracts with good recoveries, however the method is time consuming, often requiring several hours to extract a single sample. In addition, emulsion formation with some organic solvents may hinder phase separation, resulting in inconsistent recovery (Tebbett and Mc Cartney, 1988).

The prevalence of illegal drug use in this country, as stated earlier, has necessitated the need to detect and identify drugs of abuse. This has brought about the relatively new types of screening procedures. The accepted approach is to use preliminary screening tests, followed by more specific confirmatory assays. A wide variety of drug screening methods, each with its peculiar advantages and drawbacks may be utilized, including radioimmunoassay (RIA), enzyme immunoassay (EIA), thin-layer chromatography (TLC), gas chromatography (GC), high performance liquid chromatography (HPLC), and fluorescence polarization immunoassay (FPIA). FPIA has been used by the Abbott $T D_{x}$ instrument since 1981 for therapeutic drug monitoring and since 1987 for the screening of abused drugs (Jolley, 1981 and Caplan et. al., 1987). A derivative of the $T D_{x}$, the $A D_{x}$, which is dedicated solely to screening specimens for the major classes of abused drugs, was introduced in 1988. (Caplan and Levine 1988). And its entry into the forensic field has, therefore, been relatively recent (Table 2).

Immunoassays are based on specific antigen-antibody reactions. The primary advantage of immunoassay is its 
14.

Table 2. FPIA Cocaine Metabolites Assay Sensitivity and Specificity

1. Good Screening Method

2. Benzoylecgonine Target compound (inactive metabolite)

3. Some Cross-Reactivity

4. Semi-Quantitative

\begin{tabular}{|c|c|c|c|}
\hline TEST CPD. & $\begin{array}{l}\text { CONC. ADDED } \\
(\mathrm{mcg} / \mathrm{ml})\end{array}$ & $\begin{array}{l}\text { CONC. FOUND } \\
(\mathrm{mcg} / \mathrm{ml})\end{array}$ & $\begin{array}{l}\text { \% CROSS- } \\
\text { REACTIVITY }\end{array}$ \\
\hline Cocaine & $\begin{array}{r}100.0 \\
10.0 \\
1.0\end{array}$ & $\begin{array}{r}0.79 \\
0.04 \\
\text { ND }\end{array}$ & $\begin{array}{l}0.8 \\
0.4 \\
-\end{array}$ \\
\hline Ecgonine & $\begin{array}{r}10.0 \\
1.0\end{array}$ & $\begin{array}{r}0.03 \\
\text { ND }\end{array}$ & 0.3 \\
\hline $\begin{array}{l}\text { Ecgonine } \\
\text { Methyl Ester }\end{array}$ & $\begin{array}{r}100.0 \\
10.0\end{array}$ & $\begin{array}{r}0.03 \\
\text { ND }\end{array}$ & $<0.1$ \\
\hline
\end{tabular}


ability to detect small concentrations of drugs in body fluids and organs. This technique offers the best approach for detecting low drug levels associated with recreational drug use. The advantages of FPIA over other immunoassay methods such as radioimmunoassay (RIA) or enzyme multiplied immunoassay technique (EMIT) are nonradioactivity and stable calibration curves.

Drug detection by FPIA uses an inverse relationship between polarization and concentration. The exceptional sensitivity and precision at low concentrations minimize false-positive and false-negative results (Cone et. al., 1988). The Abbott instrument, the ADx, uses competitive binding and fluorescence polarization for detecting drugs of abuse in urine. A known amount of fluorescein-labeled drug competes with free drug in the sample for antibody binding sites. When bound to the antibody, the labelled drug rotates more slowly: thus, high levels of polarization correspond to low sample drug levels. Conversely, when the drug is free in the solution, it rotates more rapidly. Therefore, low levels of polarization correspond to high drug sample levels. The ADx measures polarization values and calculates the concentration from a previously stored calibration curve. The technology affords the screening of large numbers of samples at a time and yields a semi-quantitative result. 


\section{EXPERIMENTAL}

Medical examiner cases from January 1989 to June of 1989 were reviewed. Pertinent data was recorded in spreadsheet format to easily refer to the cases and for summarizing results. There were 307 cases included in this investigative study, all analyses were recorded as well as medical examiner data of significance. The data that was recorded on the spread-sheet was as follows: the medical examiner case number, age, sex, race, cause of death, manner of death, survival time, vitreous humor specimen available, urine specimen avaiable, urine immunoassay results, urine GC/MS results, blood specimen available, blood immunoassay results, blood GC/MS results (Appendix A). The cases that were selected to have vitreous samples analyzed met the following citeria: the vitreous sample had not previously been analyzed, and the case had cocaine and/or metabolites detected in blood or urine samples.

Forty-eight vitreous humor samples were selected for this study. The vitreous specimens had been stored at $-20^{\circ} \mathrm{C}$. since being received in the laboratory from the medical examiner. There were four negative controls which were included in the study; there was no cocaine and/or metabolites detected in the bloods or urines of these cases.

The vitreous humor specimens were analyzed by fluorescence polarization immunoassay (FPIA) without any pretreatment, dilution, or centrifugation. The $A b b o t t ~ A D_{x}$ analyzer 
was employed for the FPIA analysis. The calibrators, controls, and reagents were supplied by Abbott Laboratories. The instrument was operated in accordance with the Abbott operators manual for this instrument. Six calibrators were assayed and a valid calbration curve was derived by averaging the net polarization values (Figure 2). The assay requires a 50 microliter sample to be run on the assay. The assertion was that the simplistic compositon of vitreous humor specimen would allow for this facilitated screening technique to be utilized. The sensitivity for the cocaine metabolite (benzoylegonine) assay was lowered to a threshold which allowed for low level positives in vitreous to be identified. This presumptive screening process has already been mentioned as one which detects the primary metabolite of cocaine, benzoylecgonine, in human urine specimens. The reagent system demonstrates selective reactivity and high specficity. Benzoylecgonine has a reactivity of $100 \%$, whereas cocaine, ecgonine methyl ester and ecgonine cross react with the assay at less than 18 . The technique has superior sensitivity which allows for an adjustable minimum allowable threshold. Below this threshold, the safety zone extends to the stated sensitivity of the assay (Mccord and Mccutcheon, 1988). The stated minimum allowable threshold for the cocaine/ benzoylecgonine assay is 0.30 micrograms per milliliter $(\mathrm{mcg} / \mathrm{ml})$ and the sensitivity of the assay is $0.03 \mathrm{mcg} / \mathrm{ml}$ or 30 nanograms per milliliter which is based on the specifications of the instrument. 


\begin{tabular}{|c|c|c|}
\hline Calibrator & $\begin{array}{c}\text { Concentration } \\
\mathrm{ng} / \mathrm{mL} \\
\end{array}$ & Calibrator AVG P Values \\
\hline A & 0.0 & 217.14 \\
\hline B & 300 & 172.39 \\
\hline $\mathrm{C}$ & 1000 & 133.23 \\
\hline$D$ & 2000 & 112.33 \\
\hline$E$ & 3000 & 100.35 \\
\hline$F$ & 5000 & 84.08 \\
\hline
\end{tabular}

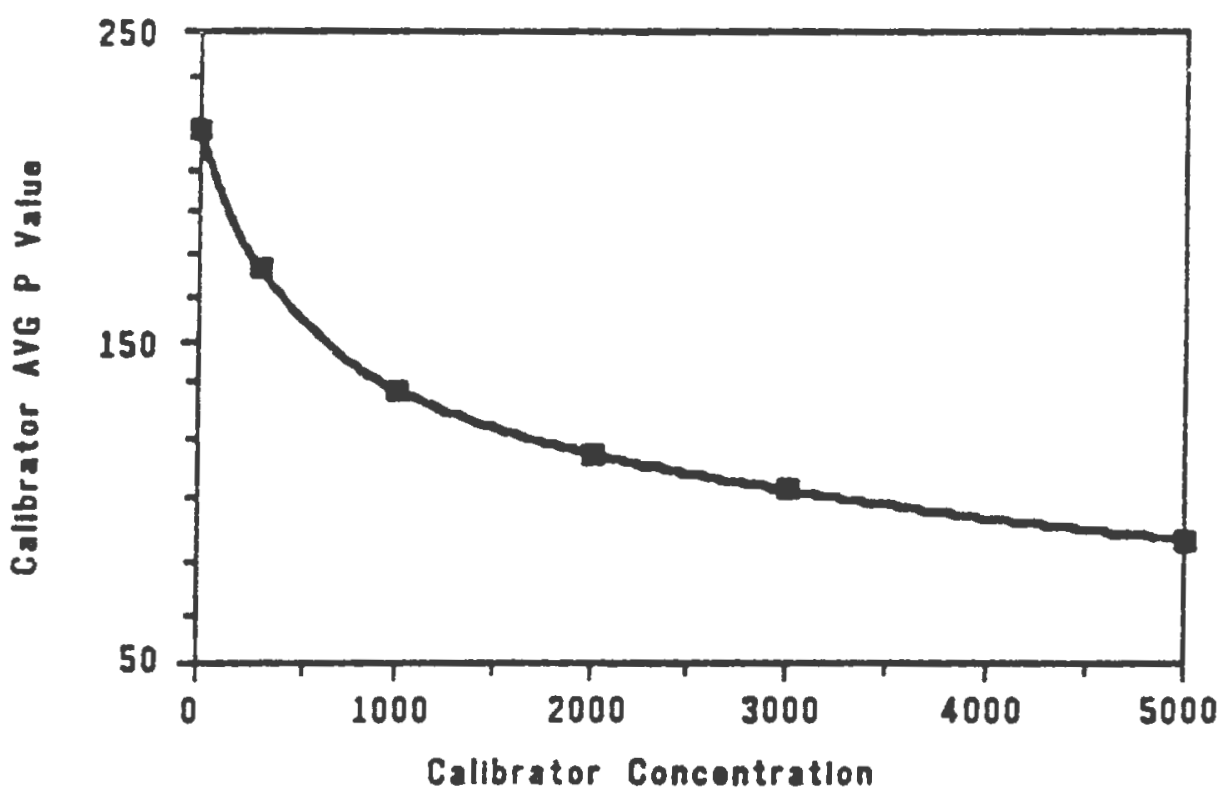

Fig. 2. FPIA Calibration Curve demonstrating Inverse Relationship between Polarization and Concentration 
In forensic toxicology work, any preliminary or presumptive positive on an initial screening test must be confirmed by a confirmatory test. It is generally agreed in the forensic community that gas chromatography coupled with mass spectrometry (GC/MS) offers the best means for the unequivocal identification of drugs and their metabolites in biological materials.

A Hewlett-Packard 5890 gas chromatograph interfaced with a Hewlett-Packard 5970 Series mass selective detector (MSD) was used for GC/MS analysis. The data system in use was the HP RTE-A computer system - The MSD was operated in the electron impact (EI) mode at $70 \mathrm{eV}$ with an ion source temperature of $280^{\circ} \mathrm{C}$ and an $\mathrm{m} / \mathrm{z}$ range from 40 to 500 . The instrument was autotuned with perfluorotributylamine (PFTBA) (Appendix $C$ ). The gas chromatograph column was an HP-I coated fused-silica $12 \mathrm{~m} \times 0.2 \mathrm{~mm} \times 0.33$-um film thickness. The GC was operated on a temperature program from $60^{\circ}$ to $250^{\circ} \mathrm{C}$, increasing at a rate of $30 \% \mathrm{~min}$ and the injection was splitless. The MSD was operated using electron impact ionization and in the selected ion monitoring mode (SIM). The ions monitored for each compound were $213 \mathrm{~m} / \mathrm{z}$ and $210 \mathrm{~m} / \mathrm{z}$ for benzoylecgonine- $D_{3} \quad\left(B Z E-D_{3}\right)$ and benzoylecgonine (BZE), respectively and $185 \mathrm{~m} / \mathrm{z}$ and $182 \mathrm{~m} / \mathrm{z}$ for cocaine- $\mathrm{D}_{3}\left(\right.$ COC $\left.-\mathrm{D}_{3}\right)$ and cocaine ( $\mathrm{COC}$ ) (Figures 3,4$)$. In the selected ion monitoring mode the MSD can be set to monitor only those ions that are characteristic of the specific compounds. Since selective scanning permits the mass analyzer to dwell longer 

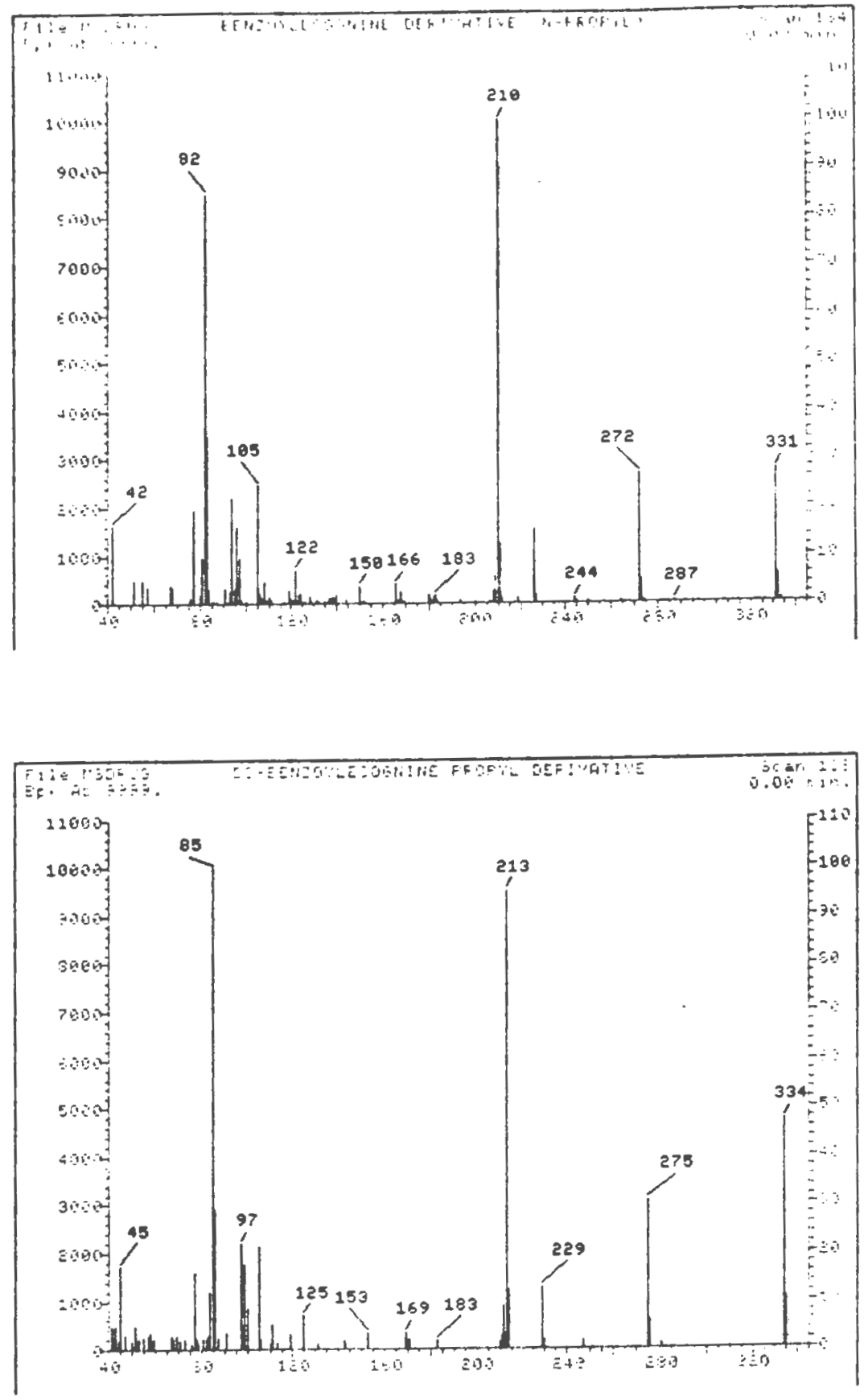

Fig. 3. Mass Spectra of Benzoylecgonine and BenzoylecgonineD3 

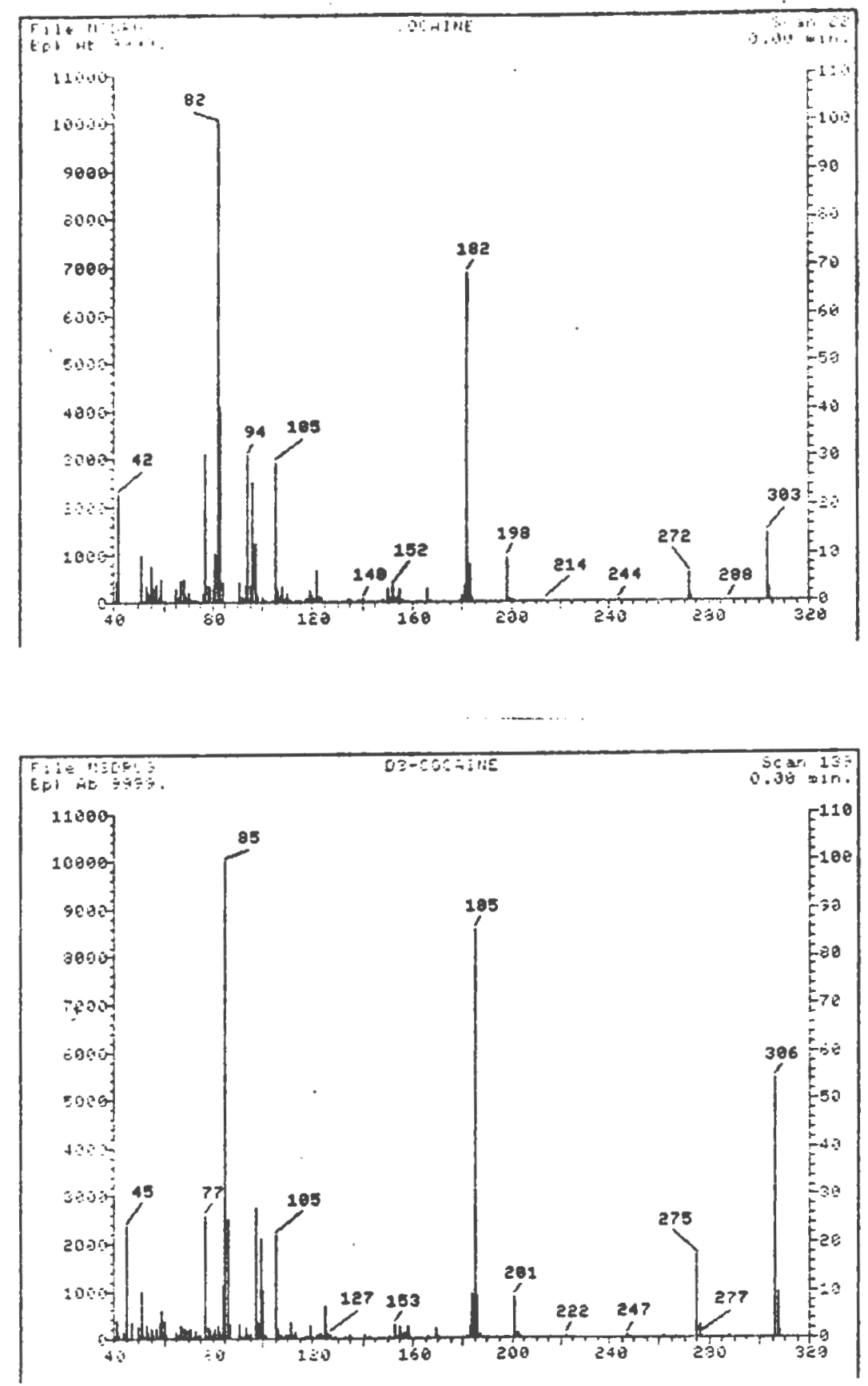

Fig. 4. Mass Spectra of Cocaine and Cocaine-D3 
on specific masses, this mode is far more sensitive than total ion scanning. It permits analysis of selected compounds at very low levels in very complex mixtures - mixtures that may be too complex for resolution by gas chromatography alone. The retention times obtained in the total ion chromatogram (TIC) were $9.11 / 9.12$ and $9.66 / 9.67 \mathrm{~min}$. for cocaine and benzoylecgonine, respectively (Figure 5). All standards were specialty analytical standards obtained from Radian Corporation. These were pure standards in methanol at a concentration of $10 \mathrm{mcg} / \mathrm{ml}$. The standards included cocaine, trideuterated cocaine (cocaine- $\left.D_{3}\right)$, benzoylecgonine, and trideuterated benzoyl-ecgonine (benzoylecgonine- $D_{3}$ ). These standards were diluted accordingly to allow for a standard curve calibration from $25 \mathrm{ng} / \mathrm{ml}$ to $1.0 \mathrm{mcg} / \mathrm{ml}$. There were three levels of control urine specimens run along with the research samples to validate the derived calibration curve. These controls (CON-DOA) were purchased from Diagnostics Products corporation (DPC) and were in the following concentrations: $0.18,0.36$, and $1.5 \mathrm{mcg} / \mathrm{ml}$.

The confirmation procedure required the solid phase extraction (SPE) of the standards, controls, and samples. This was accomplished by the use of Extrelut ${ }^{R}$ extraction columns purchased from Analytichem International. These are disposable extraction columns designed for rapid sample preparation by a highly efficient liquid/liquid extraction. The SPE columns contain a specially modified form of diatomaceous earth. The analytes in the aqueous samples are 


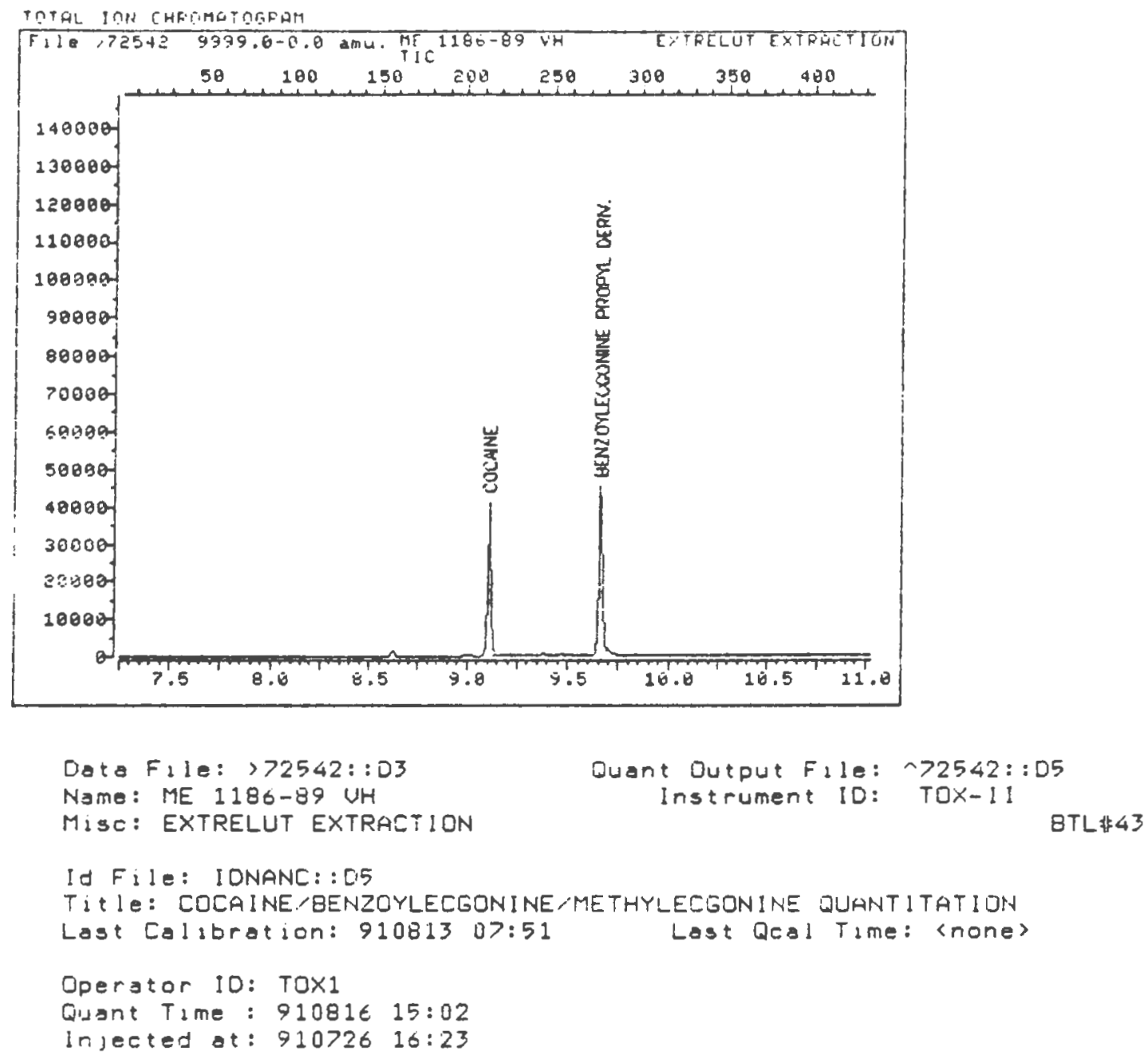

Fig. 5. Total Ion Chromatogram (TIC) of Extracted Vitreous Humor Sarmle 
adsorbed and distributed into a thin film over the hydrophilic packing. In this manner, background interferences are removed from the analysis.

All standards, controls and samples were analyzed by the same cocaine/benzoylecgonine procedure (Appendix D) adapted from Isenschmid (Isenschmid et. al., 1988). Into a clean $10 \mathrm{ml}$ test tube, $1 \mathrm{ml}$ of aqueous sample, $2 \mathrm{ml}$ of phosphate buffer $(\mathrm{pH} 7.0)$, and 100 microliters of internal standards $\left(C O C-D_{3}\right.$ and $B Z E-D_{3}$ at concentrations of 500 nanograms each) are pipetted. This chemical cocktail is vortexed and added to an SPE extraction column. The mixture is adsorbed for 4 to 5 minutes. The analytes are eluted into a disposable $15 \mathrm{ml}$ centrifuge tube with two aliquots of 9:1 chloroform: isopropanol. The sample is then evaporated to dryness in a heated waterbath $\left(50-60^{\circ} \mathrm{C}\right)$ under a stream of nitrogen to prevent oxidation. After dryness, the benzoylecgonine (if present) is derivatized to n-propyl cocaine by boiling over an open flame with 100 microliters of n, n-dimethylformamide-di-npropyl acetal for 30 seconds (Figure 6). When cool, $1 \mathrm{ml}$ of IN sulfuric acid is added to the tube and it is mixed well. The sample is cleaned up to remove impurities when $3 \mathrm{ml}$ of toluene: heptane: isoamyl alcohol (76:20:4) is added to the aqueous portion, mixed and the organic layer is discarded. The aqueous portion is next neutralized with $2 \mathrm{ml}$ of sodium carbonate buffer ( $\mathrm{pH} 9.0)$. The sample is extracted with $3 \mathrm{ml}$ of the toluene: heptane: isoamyl alcohol mixture, mixed and the organic phase is transferred to a clean conical centrifuge 

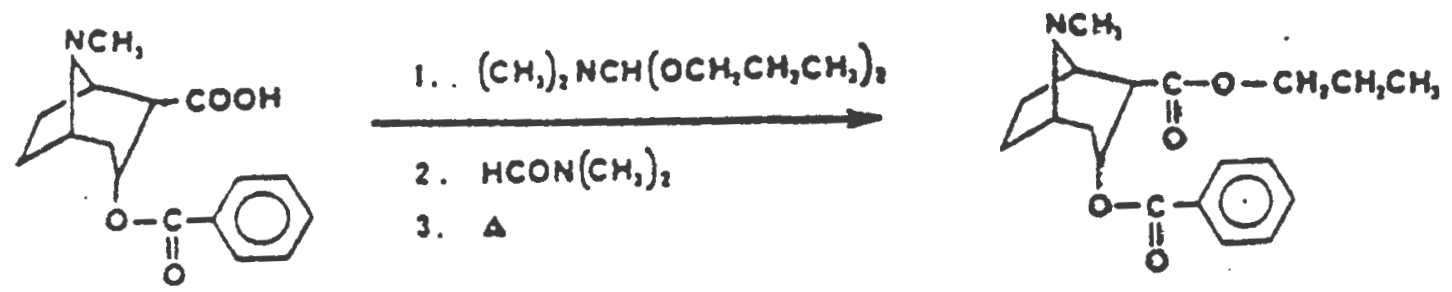

Fig. 6.

REACTION EOA THE DERIVATIZATION OF BENZOYLECGONINE TO N-FROPYL COCAINE 

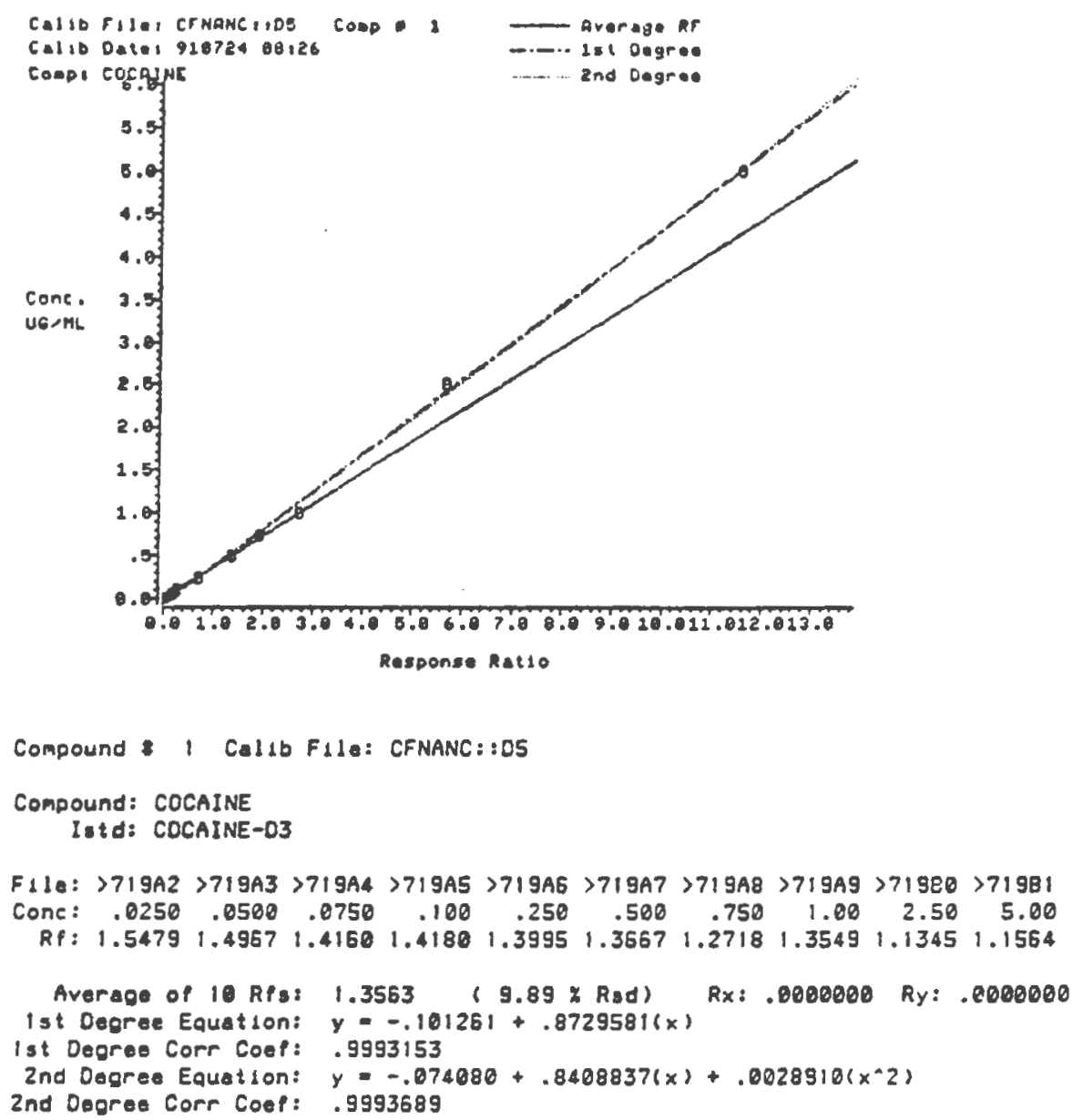

In the above equations:

$y=\frac{\text { Cone } 5 t d}{\text { Conc Istd }} \quad x=\frac{\text { Aree std }}{\text { Arod Isto }}$

Istd Conc for all caldbration points is: .500

Fig. 7. Calibration Curve of Cocaine by GC/MS 


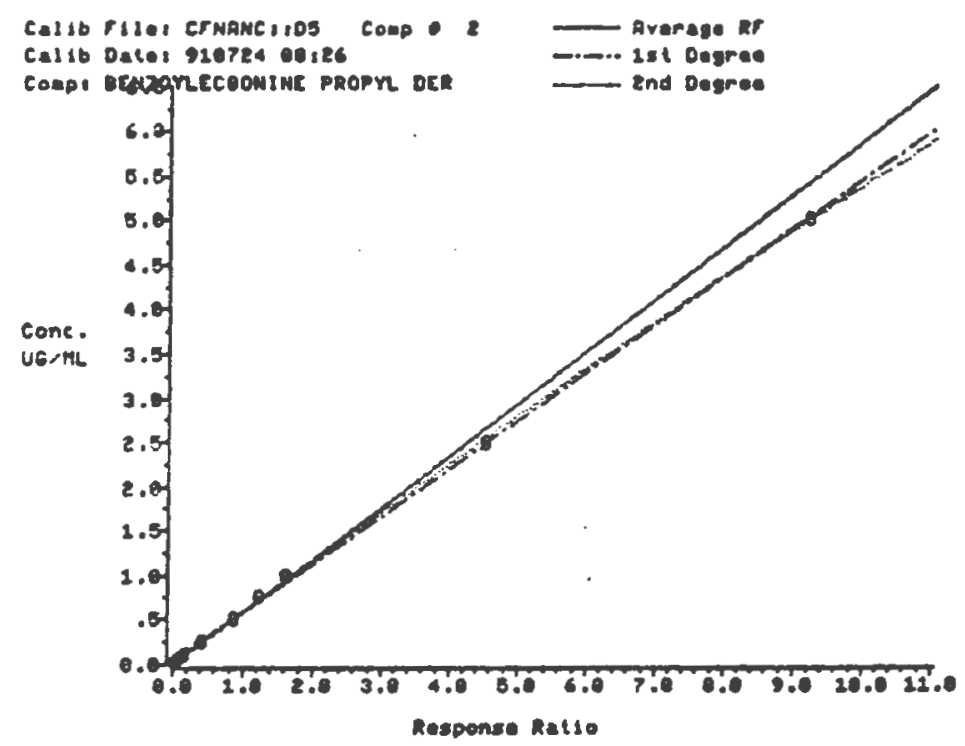

Compound * 2 Callb File: CFMaNC: 05

COMPounds BENZOYLECGONINE PROPYL DER

istd: BENZOYLECGONINE PROPYL DERIV.

F110: >718A2 >719A3 >719A4 >719A5 >719A6 >719A7 >719A8 >719A9 271980 >71981 Conc: $\begin{array}{lllllllllll}.0250 & .0500 & .0750 & .100 & .250 & .500 & .750 & 1.00 & 2.50 & 5.00\end{array}$

Rf: $.89390 .83442 .79362 .81493 .85639 .87263 \quad 82032.80217 .90439 .92177$

Averapo of 10 Rfs: .85145 ( 5.31 \& Rad) Rxs .0000000 Ry: .0000000

1.t Degree Equation: $y=.0585702+1.083699(x)$

Ist Dogree Corr Coef: .9996432

2nd Degree Equation: $y=.0251851+1.158802(x)+-.008517\left(x^{-} 2\right)$

2nd Degrse Corr Cosf: .9998112

In the ebove equetions:

$y=\frac{\text { Cone Std }}{\text { Conc Iatd }} \quad x=\frac{\text { Aroe Std }}{\text { Aroe Iotd }}$

Istd Conc for ell calibration points is: .500

Fig. 8. Calibration Curve of Benzoylecgonine by GC/MS 
tube and evaporated to dryness under a stream of nitrogen. The dried sample is then reconstituted with 100 ul of chloroform and 3 ul are injected into the GC/MS for mass spectral analysis.

standard curves for cocaine and benzoylecgonine were established by running series of standards from 25 to 1000 $\mathrm{ng} / \mathrm{ml}$ (Figures 7,8 ). The calibration curve for benzoylecgonine produced a slope of 1.083 , zero intercepts and a correlation coefficient of 0.999. The procedure was determined to be reliably linear for concentrations between 0.030 and $1.00 \mathrm{mcg} / \mathrm{ml}$. Quantitations for the analytes were achieved by comparing the abundance of the major ions and retention times of the selected ion chromatogram of the analytes with the corresponding internal standard (Table 3). 
Operator 10: TOX1

Output File: $A>2542:: 05$

Do:o File: $>>2542:: 03$

Nain: ME $1186-89$ UH

MISE: EXTRELUT EXTRACTION
QUANT REPORT

Quant Rev: ?

$$
\begin{array}{r}
\text { Injected of: } 9: 172010: 23 \\
\text { D.lution factor: } 1.00000 \\
\text { !nstrument iD: TOx-11 }
\end{array}
$$$$
\text { BTL } \$ 43
$$

I0 File: IONANE: :05

\begin{tabular}{|c|c|c|c|c|c|c|}
\hline & Eompound & R.T. Q ion & Area & Coric & Unats & $q$ \\
\hline 11 & - EDCAINE-DI & 9.11185 .2 & 42983 & .500 & $U G M L$ & 86 \\
\hline & COCAINE & $9.12 \quad 182.2$ & 2879 & .0180 & UG $/ M L$ & 0 \\
\hline & - BENZOYLECGONINE PROPYL DERIU. & 9.66213 .2 & 29260 & .500 & UG/ML & 14 \\
\hline 4) & BENZOYLECGONINE PROPYL DER & 9.67210 .2 & 26084 & .541 & UG/ML & 86 \\
\hline
\end{tabular}

TIIIE: COCAINE/BENZOYLECGONINE/METHYLESGONINE QUANTITATION

Last Calioration: 910813 07:51 Last QCal Time: inenas

- Compound as $15 T 0$

Table 3. GC/MS quantitation Report showing Retention times, Ion Abundance and Calculated Concentrations 
IV. RESULTS

From the 307 cases researched, 48 were selected to be included in this study. These cases were selected to analyze for the concentration of benzoylecgonine in the vitreous humors and to compare these to the blood concentrations of the same analyte. Of these selected 48 cases, 3 were determined to have vitreous samples that were of insufficient quantity to allow for FPIA and GC/MS determinations. This allowed for 45 samples to be selected to be analyzed by FPIA and GC/MS. These samples included four negative controls, which gave FPIA readings of zero.

For the purpose of this study, any FPIA reading greater than zero was initially considered a positive, which required further testing. Of the total cases reviewed ( $n=307), 41$ vitreous results by FPIA were obtained, which represented approximately $13 \%$ of the total cases. These vitreous positives by FPIA were separated into three categories (Table 4). The first category which represented $7.3 \%$ of the 41 samples had FPIA readings $>0$ but $<0.03 \mathrm{mcg} / \mathrm{ml}$. The second category which comprised $41.5 \%$ of the samples had FPIA readings $>$ or $=$ to $0.03 \mathrm{mcg} / \mathrm{ml}$ but less than $0.30 \mathrm{mcg} / \mathrm{ml}$ (the standard threshold level). The third category was the vitreous humors with FPIA readings $>$ or $=0.30 \mathrm{mcg} / \mathrm{ml}$, and this accounted for $51.2 \%$ of the cases.

The majority of the vitreous humors tested were above the standard threshold level of $0.30 \mathrm{mcg} / \mathrm{ml}$. However, a signi- 
Table 4. Medical Examiner Cases with Vitreous Humor Samples Analyzed for Cocaine Metabolites

87\% Medical Examiner Cases - Vitreous Humor Samples negative

13\% Medical Examiner Cases - Vitreous Humor Samples $>0 \mathrm{mcg} / \mathrm{ml}(\mathrm{n}=41)$

$7.3 \%$ FPIA $<0.03 \mathrm{mcg} / \mathrm{ml}$

$41.5 \%$ FPIA readings $>$ or $=0.03 \mathrm{mcg} / \mathrm{ml}$

$51.2 \%$ FPIA readings $>$ or $=0.30 \mathrm{mcg} / \mathrm{ml}$ 
ficant number of samples, $41 \%$, fell between greater than 0.03 $\mathrm{mcg} / \mathrm{ml}$ and less than $0.30 \mathrm{mcg} / \mathrm{ml}$. If only vitreous humor was analyzed for these cases, these would not have been further investigated under conventional forensic toxicology guidelines.

The vitreous humor initial screening results were compared with benzoylecgonine levels determined by GC/MS. An attempt was made to see if a correlation existed between the FPIA technique (which screens primarily for benzoylecgonine) and the benzoylecgonine level determined by solid phase extraction and analysis by GC/MS (Table 5). The correlation coefficient for the two assays was 0.701 (Table 6). Although there was relationship between the two assays, there were several outliers (Figure 9). A correlation is a mathematical statistic that indicates the degree to which two variables are associated. If the correlation is squared (which varies from 0.0 to 1.0 ), then one gets a mathematical description of the proportion of one variable that explains the occurrence of the second variable. The scatter plot amd the regression line are shown in Figure 9.

The GC/MS results of the vitreous humor samples were then compared with the GC/MS results of the corresponding blood samples (Table 7). Specifically, the benzoylecgonine quantitations were compared to calculate the correlation coefficient between the two analyses. The correlation between these two biological specimens for the same analyte was 0.510 (Table 8 ). The scatter plot and the regression line are shown 
Table 5. Data showing Vitreous Humor Sample I.D. \#, FPIA Reading, and GC/MS Benzoylecgonine Quantitation

$\begin{array}{llll}\text { I.D. \# FPIA GC/MS } & \text { I.D.\# FPIA GCMS }\end{array}$

$\begin{array}{lllllll}1 & \text { ME0122 } & 0.00 & 0.00 & 39 \text { ME1838 } & 1.05 & 1.02 \\ 2 & \text { ME0354 } & 0.00 & 0.00 & 40 \text { ME0814 } & 1.08 & 1.29 \\ 3 & \text { ME0118 } & 0.00 & 0.00 & 41 \text { ME1530 } & 1.29 & 2.71 \\ 4 & \text { ME0311 } & 0.00 & 0.00 & 42 \text { ME1935 } & 1.38 & 0.83 \\ 5 & \text { ME1665 } & 0.01 & 0.00 & 43 \text { ME0006 } & 1.80 & 2.38 \\ 6 & \text { ME0453 } & 0.02 & 0.03 & 44 \text { ME0260 } & 2.01 & 2.87 \\ 7 & \text { ME1557 } & 0.02 & 0.23 & 45 \text { ME1901 } & 2.59 & 0.90 \\ 8 & \text { ME0328 } & 0.03 & 0.09 & & & \\ 9 & \text { ME1571 } & 0.03 & 0.04 & \text { Units }=\mathrm{mcg} / \mathrm{ml} & \end{array}$

$\begin{array}{lll}10 \mathrm{ME} 0976 & 0.03 & 0.01\end{array}$

11 ME0878 $0.03 \quad 0.03$

12 ME0443 $0.05 \quad 0.27$

13 ME0965 $\quad 0.05 \quad 0.29$

14 ME2027 $0.08 \quad 0.03$

15 ME1653 $\quad 0.10 \quad 0.21$

16 ME1090 $0.11 \quad 0.17$

17 ME0027 $0.11 \quad 0.16$

$18 \mathrm{ME0536} \quad 0.14 \quad 0.26$

19 ME0092 $0.18 \quad 0.29$

20 ME0007 $0.21 \quad 1.71$

21 ME1229 $0.23 \quad 0.24$

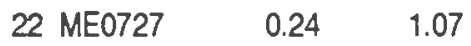

23 ME1676 $0.24 \quad 0.31$

24 ME0820 $0.26 \quad 1.16$

25 ME1512 $\quad 0.33 \quad 0.39$

$\begin{array}{lll}26 \text { ME1812 } & 0.33 & 0.57\end{array}$

27 ME1440 $\quad 0.41 \quad 1.07$

28 ME2009 $\quad 0.50 \quad 0.17$

29 ME0175 $\quad 0.51 \quad 1.11$

$\begin{array}{lll}30 \text { ME1991 } & 0.51 \quad 0.65\end{array}$

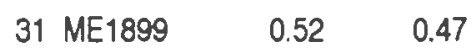

$\begin{array}{lll}32 \text { ME0156 } & 0.54 & 1.28\end{array}$

$\begin{array}{lll}33 \text { ME0287 } & 0.80 \quad 0.86\end{array}$

$\begin{array}{lll}34 \text { ME1811 } & 0.85 & 0.41\end{array}$

35 ME0286 $\quad 0.90 \quad 1.01$

$\begin{array}{lll}36 \text { ME1186 } & 0.98 & 0.54\end{array}$

$\begin{array}{lll}37 \text { ME2005 } & 0.99 & 1.23\end{array}$

$\begin{array}{lll}38 \text { ME1855 } & 1.02 & 0.58\end{array}$ 
34.

Table 6. Linear Regression Analysis of Vitreous Humor

FPIA vs. GC/MS Results

Regression Output:

Constant

0.118228

Std Err of Y Est

0.429233

R Squared

0.497603

No. of Observations

45

Degrees of Freedom

43

$x$ Coefficient(s)

0.595707

Std. Err of Coef.

0.091281

Correlation coefficient $\quad 0.701$ 
35.

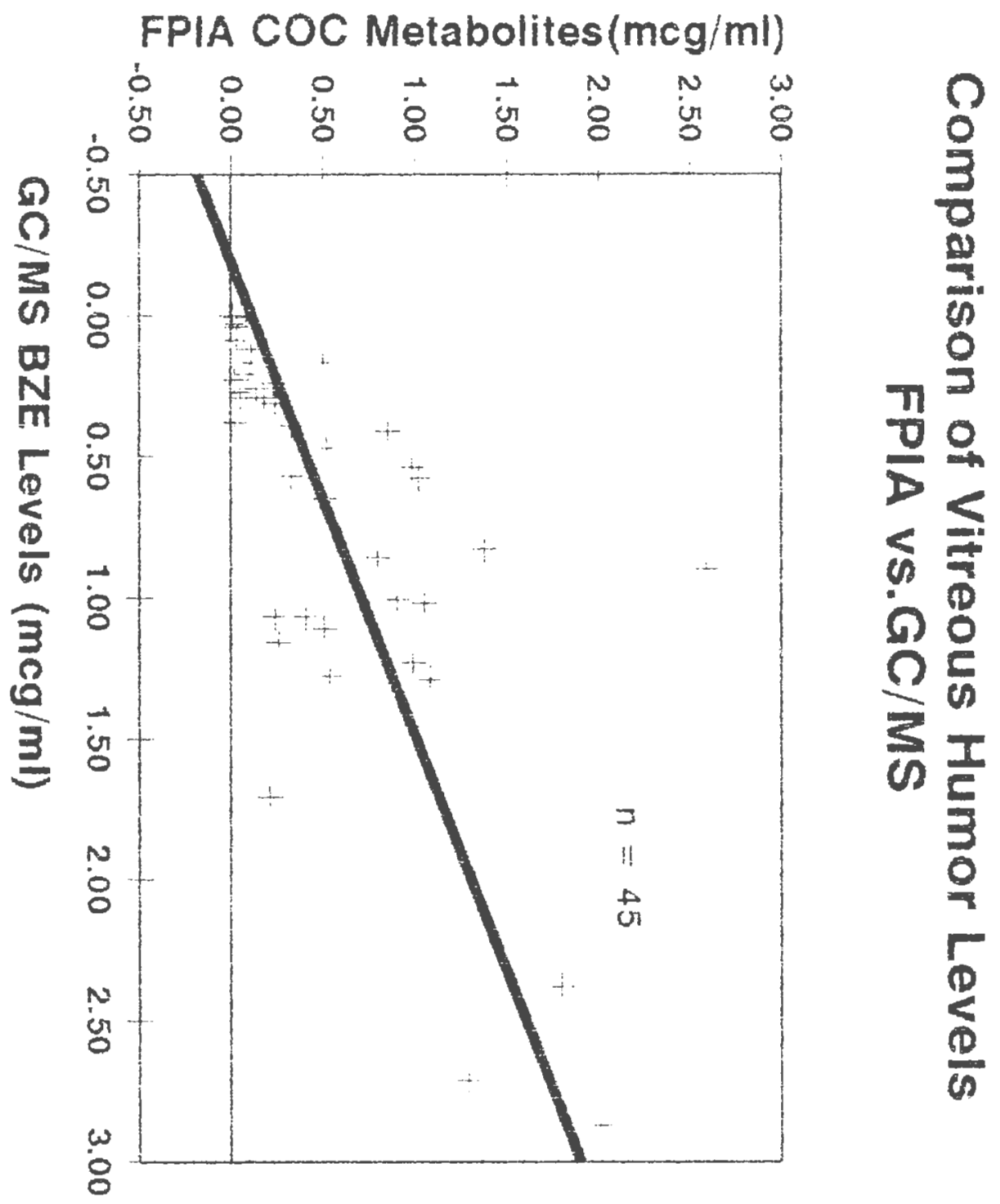

Fig.9. Scatter plot of Vitreous Humor Levels by FYIA vs. GC/MS 
36.

Table 7. Data of Vitreous Humor Benzoylecgonine Levels

by GC/MS and Blood Benzoylecgonine Levels by GCMS

1.D. \# Vitreous Humor Blood

$$
\text { GC/MS GC/MS }
$$

1 ME1665

2 ME0122

3 ME0354

4 ME0311

5 ME0118

6 ME0976

7 ME2027

8 ME0878

9 ME1571

10 ME0328

11 ME0027

12 ME2009

13 ME1090

14 ME1653

15 ME1557

16 ME1229

17 ME0536

18 MEO443

19 ME0965

20 ME0092

21 ME1676

22 ME0453

23 ME1512

24 ME1811

25 ME1899

26 ME1186

27 ME1812

28 ME1855

29 ME1991

30 ME1935

31 ME0287

32 ME1901

33 ME0286

34 ME1838

35 ME0727

36 ME1440

37 ME0175

38 ME0820

39 ME2005

40 ME0156
$0.00 \quad 0.00 * 0.00$ BZE IN URINE

$0.00 \quad 0.00$ *NEG CONTROL

$0.00 \quad 0.00$ *NEG CONTROL

$0.00 \quad 0.00$ *NEG CONTROL

$0.00 \quad 0.00$ *NEG CONTROL

$0.01 \quad 0.06$

$0.03 \quad 0.33$

$0.03 \quad 0.10$

$0.04 \quad 0.07$

$0.09 \quad 0.10$

$0.12 \quad 0.46$

$0.17 \quad 0.00 * 0.40$ BZE IN URINE

$0.17 \quad 1.12$

$0.21 \quad 0.14$

$0.23 \quad 0.04$

$0.24 \quad 0.13$

$0.26 \quad 0.59$

$0.27 \quad 0.07$

$0.29 \quad 0.72$

$0.29 \quad 0.12$

$0.31 \quad 0.76$

$0.03 \quad 0.00 * 0.34$ BZE IN URANE

$0.39 \quad 0.45$

$0.41 \quad 0.42$

$0.47 \quad 0.42$

$0.54 \quad 0.56$

$0.57 \quad 0.25$

$0.58 \quad 0.53$

$0.65 \quad 0.71$

$0.83 \quad 0.82$

$0.86 \quad 1.92$

$0.90 \quad 0.77$

$1.01 \quad 0.34$

$1.02 \quad 2.19$

$1.07 \quad 0.60$

$1.07 \quad 1.42$

$1.11 \quad 1.60$

$1.16 \quad 0.29$

$1.23 \quad 4.52$

$1.28 \quad 1.06$
1.D. \# Vitreous Humor Blood

GC/MS GC/MS

$\begin{array}{lll}41 \text { ME0814 } & 1.29 & 1.52\end{array}$

42 ME0007 $\quad 1.71 \quad 1.34$

43 ME0006 $\quad 2.38 \quad 0.56$

44 ME1530 $2.71 \quad 2.03$

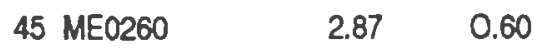

Units $=\mathrm{mcg} / \mathrm{ml}$ 
Table 8. Linear Regression Analysis of Vitreous Humor Benzoylecgonine Levels by GC/MS and Blood Benzoylecgonine Levels by GC/MS

Regression Output:

Constant

Std Err of Y Est

R Squared

No. of Observations

Degrees of Freedom

$X$ Coefficient(s)

Std. Err. of Coef.

Correlation Coefficient
0.355201

0.617418

0.260023

45

43

0.426367

0.111333

0.51 
38.

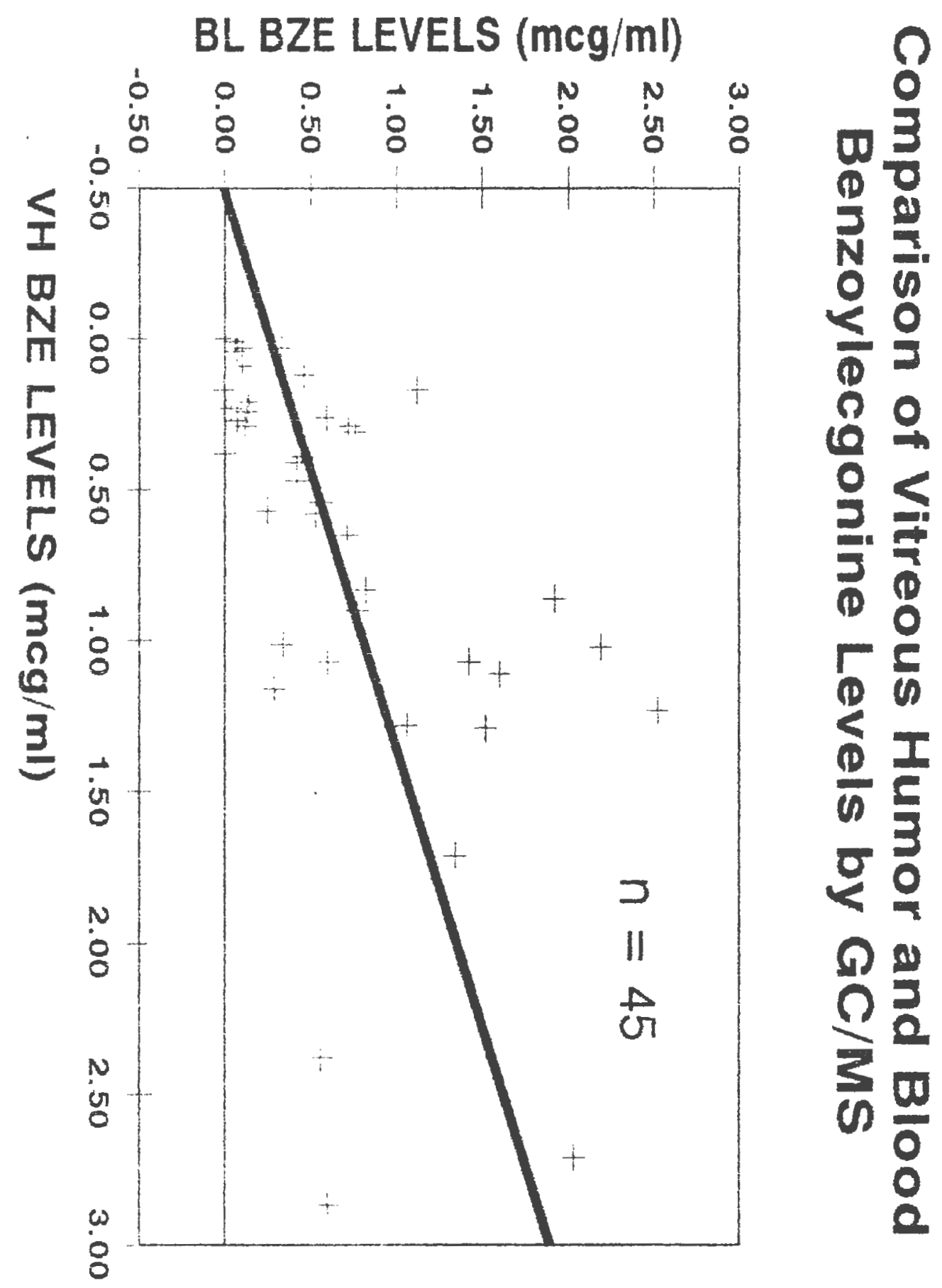

Fig. 10. Scatter plot of Vitreous Humor and Blood Benzoylecgonine levels by GC/MS 
in Figure 10.

All four negative controls correlated well by FPIA and GC/MS, therefore exhibiting no false positives. In two cases, the FPIA results on vitreous humor were positive, yet the corresponding blood samples were negative. In these two cases, the urines were positive for benzoylecgonine, therefore it might indicate a lag time in the elimination of the drug. This has been demonstrated in the laboratory for other drugs, such as ethanol (Caplan and Levine, 1990). One case gave a positive FPIA result in vitreous $(0.01 \mathrm{mcg} / \mathrm{ml})$, and no benzoylecgonine was detected by GC/MS. Technically, due to the limits of the assay this is below the $0.03 \mathrm{mcg} / \mathrm{ml}$ senstivity of the assay and therefore would not be considered a true false positive. Both the blood and the urine in this case were negative for the presence of benzoylecgonine (Table 9).

The confirmation analyses provided full concordance data between the two assays. The DPC controls run to validate the GC/MS calibration curve gave accurate quantitations. (Table 10) 
Table 9. Summary of Analyses of Data from Vitreous Humors by FPIA and GC/MS.

* 307 Medical Examiner Cases reviewed

* 48 Cases selected for vitreous humor analyses

* 3 Cases - Vitreous humors had insufficient quantity for GC/MS quantitations

* No false negatives by FPIA

* No false positives at $0.03 \mathrm{mcg} / \mathrm{ml}$ cut-off by FPIA:

( 2 Cases - Vitreous humors - FPIA positive GC/MS positive

Blood samples negative * Urines positive *)

( 1 Case - Vitreous Humor - FPIA result $0.01 \mathrm{mcg} / \mathrm{ml}$ GC/MS none detected) 
Table 10. Accuracy check with Diagnostics Products Corp. GC/MS Control Samples

TARGET (NG/ML) ACTUAL VARIATION

CON-DOA LEVEL1

CON-DOA LEVEL2

CON-DOA LEVEL3

(GC/MS ANALYSIS)
180

360

1500
$185+/ .5 \mathrm{NG} / \mathrm{ML}$

$362+/-2 \mathrm{NG} / \mathrm{ML}$

$1550+/ .50 \mathrm{NG} / \mathrm{ML}$ 
An additional study was conducted to determine the possible explanation for the variation in some cases between the vitreous humor FPIA result and the GC/MS result for benzoylecgonine. The first assumption was that the variation in the vitreous FPIA result was due to the viscosity factor. This factor could cause the variation in the instrumental pipetting which occurs in the FPIA technique.

A pooled reserve of human vitreous humor was obtained from samples to be discarded by the Acting Chief Medical Examiner. The pooled vitreous samples equaled a volume of 50 milliliters. The pooled vitreous humor was run by FPIA initially with no drug added, to ascertain the blank reading to insure that there were no drugs present that would give a positive reading. The sample was run in 20 repetitions and the results were consistently negative. The pooled sample was then spiked with benzoylecgonine standard to attain a concentration of $1.6 \mathrm{mcg} / \mathrm{ml}$. This sample was separated into two equal volumes, one was untreated and one was treated with 10\% trichloroacetic acid (TCA). The TCA could potentially remove the protein, thereby possibly eliminating the viscosity factor as a cause of the inconsistencies. However, the CVs for both aliquots were $2.9 \%$ and $3.3 \%$ respectively (Table 11 ). The aliquot treated with $10 \%$ TCA demonstrated a reduced positive result. The mean for these 20 repetitions was $1.07 \mathrm{mcg} / \mathrm{ml}$, as opposed to the aliquot mean of $1.61 \mathrm{mcg} / \mathrm{ml}$ for the untreated.

It was thought that the addition of a proteolytic agent would eliminate the viscosity factor and allow for better 
43.

Table 11. Precision Study of pooled Vitreous Humor samplesuntreated and treated with 10\% Trichloroacetic Acid

TARGET VALUE (MCG/ML)

1.60

1.61

1.07

STD.DEV

4.6

3.5

COEF. OF VAR. (\%)

2.9

3.3

\# OF TRIALS

20

20

MEAN NET POLARIZATION

112.46

$\star 129.86$

VALUE BY FPIA

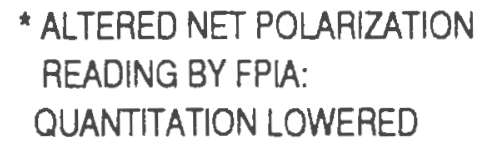


correlation between the vitreous humor FPIA result and the vitreous humor benzoylecgonine result by GC/MS. Trichloroacetic acid was selected as the agent, since it is commonly used in the laboratory to precipitate out proteins found in blood samples. The selection of $10 \% \mathrm{TCA}$ was not a good choice since the solution could react with benzoylecgonine (a tertiary amino carboxylic acid) and produce a salt, thus interfering with the extraction of the analyte. The phenyl ester on benzoylecgonine could also be de-esterified and the resulting product, ecgonine, does not react significantly with the immunoassay. The agent (10\% TCA) also exhibits some fluorescence, which would adversely affect the FPIA analysis, by causing a decrease in the quantitation. There were no inconsistencies exhibited by either aliquots, and they yielded low CV's. The most unusual finding was that the addition of $10 \%$ TCA increased the net polarization and therefore decreased the cocaine metabolite concentration by FPIA. The study could not duplicate the individual viscosity problem experienced when sampling the low volume vitreous samples. 


\section{DISCUSSION}

Fluorescence polarization immunoassay of vitreous humor as a screening process provided a qualitative prediction of the final GC/MS results. There were no false positives or false negatives by using this screening process. The initial perception of a false positive ultimately proved to be below the limits of the assay's cut-off level.

The correlation coefficient between vitreous humor benzoylecgonine levels and blood benzoylecgonine levels was 0.5. Ideally, if the drug substance is distributed by simple diffusion, at equilibrium the blood and vitreous humor levels should be identical. Studies by coe, indicated more variation between blood and vitreous humor levels (Coe and Apple, 1985). He also indicated potential difficulty in separating toxic from therapeutic levels of drugs based on vitreous humor levels alone.

From the data generated by this research and those of others, several generalizations may be made concerning the concentration of drugs in vitreous humor. The more water soluble drugs and those least affected by protein-binding factors in the blood, would be expected to readily diffuse from the blood into the vitreous humor. The drugs must have sufficient lipid solubility to penetrate the blood-vitreous barrier. In some cases in the study, the high water solubility of benzoylecgonine permitted high concentrations to be found in the vitreous, sometimes even higher than in the 
blood. There are other factors causing the variation in the distribution of the metabolite in the blood and vitreous humor. Survival times of the decedents is a definite factor, along with the time since the administration of the drug, the presence of other drugs in the system, the varying states of decomposition, and also the perimortem interval. It was demonstrated by Beno that by sampling vitreous at different perimortem intervals, the drug content of one vitreous humor could vary greatly from the other vitreous (Beno and kriewall, 1989). This variation could be due to the leaching of the drug from the high concentrations of the drug in the brain tissue.

The history in most of the cases did not afford the survival time information. In the majority of the cases, the survival time was unknown and therefore did not clarify the disparity between the two fluids. As mentioned in other studies, it had been predicted that when survival times were lengthy, the blood/vitreous ratio of an analyte might approach unity. However, this research did not clarify that assumption. Since vitreous humor is a partitioned fluid, with a $\mathrm{T} 1 / 2$ of 10 to 15 minutes, the author anticipated a good correlation with corresponding blood levels. Also, since the molecular weights of benzoylecgonine and cocaine are relatively low, 289 and 303 respectively, these low molecular compounds could diffuse rather easily. However, the ratio varied a great deal between the two biological fluids. There are more factors involved, and the most important probably 
being the difference between dosing and the time of death as indicated in the study by Poklis (Poklis et al., 1985).

The most troublesome finding was the variation between the vitreous FPIA result and the vitreous GC/MS benzoylecgonine quantitation. The FPIA technique is a semiquantitative technique which reacts $100 \%$ with the compound benzoylecgonine. However, cross reactivity with other compounds does occur at a low percentage. The other compounds if present in varying high concentrations, may be causing the apparent discrepancy between the two assays. The additional study with $10 \%$ TCA did not clarify the problem, since there were no inconsistencies demonstrated that could be attributed to the viscosity factor. The variation appears to be one which must be explained on a case by case basis. The outstanding outliers in the study were reviewed and most demonstrated no known survival time or time since dosing based on the history.

The biggest liability in the screening of vitreous humor is the lack of sufficient sample volume to repeat analyses and generate statistical data on a case by case basis. The low sample volume did not allow for repetitive analyses, which then would allow for CVs to be calculated on each sample. This is not true of blood and urine, which when available, are usually of sufficient volume.

one point for discussion is the validity of testing infants and children by vitreous humor for cocaine exposure in the absence of a urine sample. Lowering the threshold 
as was done in this study, to a level of $0.03 \mathrm{mcg} / \mathrm{ml}$ would be necessary to detect the low levels of cocaine and metabolites found in infants and children. In 25 cases reviewed of maternal substance abuse, all showed benzoylecgonine levels in the blood of the fetuses and neonates in the range of 0.12 to $3.2 \mathrm{mcg} / \mathrm{ml}$ (Sweeney, 1991). The routine drug screening of infants and children would now appear to be a modern necessity. 


\section{SUMMARY AND CONCLUSIONS}

The goal of the research was to provide a valid assessment of the fluoresence polarization immunoassay technique in detecting cocaine and/or its metabolites in vitreous humor. In all the cases reviewed, when cocaine and metabolites were present in the blood, cocaine metabolites were positive by FPIA in the vitreous humor. The research showed vitreous humor to be a reliable postmortem specimen for detecting antemortem cocaine use. It was demonstrated that elevated cocaine metabolite (benzoylecgonine) levels in blood are accompanied by elevated cocaine metabolite levels in vitreous humor. The research illustrated that the cocaine metabolites assay by FPIA has sufficient specificity and sensitivity to be a valid screening technique for vitreous samples at the low threshold of $0.03 \mathrm{mcg} / \mathrm{ml}$.

The screening of vitreous humors by FPIA when the threshold is lowered, is a useful tool in forensic toxicology. The technique, however, is just a screening one and not meant to replace the confirmation of the result. When the absolute concentration of benzoylecgonine is critical for the interpretation of results, an alternate, more specific methodology should be used for an accurate concentration; GC/MS is such an alternative.

Vitreous humor specimens provide an additional medium for analysis in postmortem cases. These specimens can be screened rapidly and relatively inexpensively by fluorescence 
50.

polarization immunoassay for qualitative results. There are more studies necessary on the ability to detect various drugs in vitreous humor. In the future, vitreous drug concentrations when compared with blood concentrations, may allow for the assessment of the time between administration of the substance and death. 
APPENDIX A.

COMPARATIVE TOXICOLOGY OF VITREOUS HUMOR AND BLOOD

\begin{tabular}{|c|c|c|c|c|c|c|c|c|c|}
\hline \multirow{3}{*}{$\#$} & \multirow{3}{*}{ CASES } & CAUSE & MAN. & & SURV. & $\mathbf{V H}$ & V.H. FPIA & V.H. GC/MS & BL. GC/MS \\
\hline & & OF & $\mathrm{OF}$ & \multirow[t]{2}{*}{ A/R/S } & TIME & $\mathbf{A V}$ & RESULTS & RESULTS & \multirow{2}{*}{$\frac{\text { RESULTS }}{\text { (MCGML) }}$} \\
\hline & & DEATH & DEATH & & (HR.) & & & (MCG/ML) & \\
\hline & JANUARY'89 & & & & & & & & \\
\hline 1 & ME0004-89 & PEND & PEND & $5 M / W / M$ & NONE & $\mathbf{Y}$ & NEG & & NDD \\
\hline 2 & ME0005-89 & ALC & NAT & 58/W/M & UNK & $\mathbf{Y}$ & N/A & & $\mathbf{N} / \mathbf{A}$ \\
\hline 3 & Meoposose & 16 & MA & $2+N W M$ & +1 & $x$ & acoophos & 238 B\%s & $0.0500 \mathrm{cos} 5 \mathrm{azB}$ \\
\hline 4 & Mooor-sos. & Rip & Hotp & 35AMM & ens & t) & 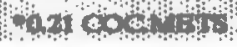 & $1.7+1+2$ & as3cocch 3 BZZE \\
\hline 5 & MEoono-89 & INJ & HOM & $46 / \mathrm{WM}$ & NONE & $\mathbf{Y}$ & $\mathbf{N} / \mathbf{A}$ & & $\mathbf{N} / \mathbf{A}$ \\
\hline 6 & ME0014-89 & ASHD & NAT & OA/BVP & NONE & $\mathbf{Y}$ & NEO & & N/A \\
\hline 7 & ME0017-89 & $\infty$ & $A O C$ & $76 / W / F$ & a.s & $\mathbf{Y}$ & BARBS & N/A & <1MCGML BUTAL \\
\hline 8 & MEO027-80 & PaND & PENo & $37 \mathrm{NWM}$ & NONI: & ; & Hil cochsts & ais Bze & NEGCOC/0.6BZR \\
\hline 9 & MEOM28-89 & INJ & ACC. & $75 / W / F$ & NONE & $\mathbf{Y}$ & $\mathbf{N} / \mathbf{A}$ & & NEG FLURAZJPAM \\
\hline 10 & MER0034-89 & $\mathbf{I N J}$ & $A C X$ & $42 / \mathrm{W} / \mathrm{M}$ & NCONE & $\mathbf{Y}$ & NEG & & $\mathbf{N} / \mathbf{A}$ \\
\hline 11 & ME0047-89 & INJ & MVA & $63 / W / F$ & s.o & $\mathbf{Y}$ & PpX & N/A & (..24PPXN/0.6ANPA \\
\hline 12 & ME0062-89 & ASHI) & NAT & S7/W/M & NONE & $\mathbf{Y}$ & NEG & & NDI) \\
\hline 13 & ME:OK6-89 & sins & SIDS & $\mathbf{I M} / \mathbf{W} / \mathbf{M}$ & MINS & $\mathbf{Y}$ & N/A & & QNS \\
\hline 14 & ME0076-89 & PEND & PEND & $11 \mathrm{M} / \mathrm{W} / \mathrm{M}$ & NONE & $\mathbf{Y}$ & NEG & & $\mathbf{N} / \mathbf{A}$ \\
\hline 15 & MI3(xo80-89 & OD & suic: & $43 / W / M$ & NONE & N & N/A & & 1.CAATPKO.SNTT'/L.SIPI X \\
\hline 16 & ML:0083-89 & INJ & MVA & $83 / W / F$ & NCSNE & $\mathbf{Y}$ & $\mathbf{N} / \mathbf{A}$ & & (LOKNORI)IAZ, \\
\hline 17 & Mi1300022-80 & AspX & sulc & $27 / \mathrm{W} / \mathrm{M}$ & NONR & $\mathbf{x}$ & -0.18 CXCLME'TS & a.30 BZE & $0.13 C 0 \times 10.12137 \mathrm{~F} / 1.121 \mathrm{MP}$ \\
\hline 18 & MEO1 18-80 & INJ & MVA & $30 / W / F$ & MINS & $x$ & "NHG/R RW & D.OA BZE & NDD \\
\hline 19 & ME0122-89 & PEND & PEND & $33 / \mathrm{WM}$ & NONE & $\mathbf{r}$ & "NECi/LSOW & $0.00 \mathrm{tzZE}$ & NIDO \\
\hline 20 & ME0139-89 & INJ & SUJIC & $64 / W / R$ & 30DAYS & $\mathbf{Y}$ & NPG & & NIJI) \\
\hline 21 & MLO(1) 50.89 & Gsw & Sulc & $8 \& / W / M$ & NONE? & $\mathbf{Y}$ & N/A & & N/A \\
\hline 22 & MEO156-8\% & PENDD & PEND & 35/12/M & 80 & $\mathbf{Y}$ & -0.54 CUCMETS & $1.28 \mathrm{BzE}$ & NECICOC./1.06H/I3 \\
\hline 23 & ME:01 59-89 & ASIID & NAT & $51 / W / F$ & NONE & $\mathbf{Y}$ & NPS; & & $\mathrm{N} / \mathrm{A}$ \\
\hline
\end{tabular}




\begin{tabular}{|c|c|c|c|c|c|c|c|c|}
\hline$M I: 0175-80$ & Aspx & sule: & $37 / W / F$ & NONI: & $\mathbf{Y}$ & $* 0.51$ C)C.MI:IS & $1.11 \mathrm{BZT \textrm {Z }}$ & 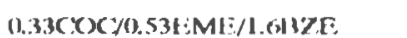 \\
\hline MI:01183-84) & Astex & AC $C^{\circ}$ & $79 / 2 / 1:$ & NONI: & $\mathbf{Y}$ & NEGi & & $N / A$ \\
\hline M[:0194-89] & DIS & NAT & $47 / \mathrm{W} / \mathrm{M}$ & 3.0 & $\mathbf{Y}$ & $N / A$ & & MEPROBAMATI: \\
\hline$M E:(0) 2(k-k)$ & INJ & MVA & $82 / W / F$ & oWKS & $\mathbf{Y}$ & $N / A$ & & (0.31TOOIMOR./0.15FIRLE: MOSR \\
\hline ME: :(24t(1-8t) & $(y) 1$ & AC': & $43 / \mathrm{W} / \mathrm{M}$ & NONI: & $\mathbf{Y}$ & $N / A$ & & $N / A$ \\
\hline MI:(10247 $\mathrm{kg}$ & Asi'X & SiJuc & $19 / \mathrm{W} / \mathrm{M}$ & NCINF: & $\mathrm{Y}$ & $N / A$ & & $\mathrm{~N} / \mathrm{A}$ \\
\hline ME:(1249-89) & $P($ NI) & SIIISS & $3 \mathrm{M} / \mathrm{W} / \mathrm{F}$ & 0.5 & $\mathbf{N}$ & $N / A$ & & $N / A$ \\
\hline$M 130252-89$ & Aspx & MVA & $15 / \mathrm{W} / \mathrm{E}$ & NONI? & $\mathbf{Y}$ & $N / A$ & & $N / A$ \\
\hline 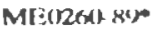 & GSW & st $11 \mathrm{C}$ & $2 \mathrm{E} / \mathrm{W} / \mathrm{M}$ & MINS & $\mathbf{Y}$ & $-2.01(x)(M E T S$ & $287 \mathrm{HZI:}$ & $0.05(8)(\% 0.6011 \mathrm{ML} / 2.5137 \mathrm{P}$ \\
\hline MF:(0261 8") & PE:NI) & PRENI) & $5(2 / 13 / M$ & NONI: & $\mathbf{Y}$ & $\mathrm{Nl}:(i$ & & NDD \\
\hline ME: $(120.5-80)$ & INJ & ACr & $4(2 / W / F$ & 0.5 & $\mathbf{Y}$ & NiGi & & NIJ) \\
\hline ME:(0278-K9) & P'I:NI) & P'ISNI) & $7 \mathbf{W K} / \mathbf{W} / \mathbf{M}$ & NONE & $\mathrm{N}$ & $N / \Lambda$ & & NIJI) \\
\hline ME0286-84 & AspX & PIEND & $23 / \mathrm{W} / \mathrm{M}$ & NONE: & $y$ & $0.90(Y)(\mathrm{ME} T \mathrm{TS}$ & 1.01 [37.? & $0.326 \times(): 0.3413 \%, 1:$ \\
\hline ML:0287-80 & PENID & [PIBNI) & $39 / 13 / \mathrm{M}$ & NC)NE: & $\mathbf{Y}$ & $-0.80(X) C: M E T S$ & $0 . \$ B \mathrm{H} Z \mathrm{~F}$ & 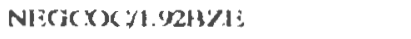 \\
\hline M1:(1289-89) & Ast II & NAT & $40 / \mathrm{W} / \mathrm{M}$ & NONI! & $\mathbf{Y}$ & $N / A$ & & $N / A$ \\
\hline MI:(1294-89) & $\mathrm{Cr}: \mathrm{I}$ & $A C x$ & $83 / \mathrm{W} / \mathrm{F}$ & 12IDAYS & $\mathbf{Y}$ & $N / A$ & & 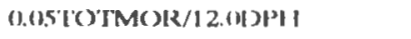 \\
\hline ME:(22(x)-K9) & INJ & ACX: & $80 / W / F$ & 1.0 & $\mathbf{Y}$ & Ni:Ci & & NIDI) \\
\hline M[:(1301-89) & PE:NI) & ['I:NI) & $11 \mathrm{M} / \mathrm{B} / \mathrm{M}$ & MINS & $\mathbf{Y}$ & Nl:Gi & & $N / A$ \\
\hline ML:00310-84) & AIC $C^{\circ}$ & $P(I N$ I) & $43 / W / F$ & NONE & $\mathbf{Y}$ & $N / A$ & & $N / A$ \\
\hline MLOBß11-890 & INJ & MVA & $23 / \mathrm{W} / \mathrm{M}$ & NONE? & $\mathrm{Y}$ & -0.01COC.MH'IS & $0 .(X) \cap 7 F$ & $N / A$ \\
\hline MII(3/2-84) & ASHI) & NAT & $39 / \mathrm{W} / \mathrm{M}$ & NeNA! & $\mathbf{Y}$ & N/A & & $N / \Lambda$ \\
\hline MI:0318-89 & DIS & NAT & $7 / \mathrm{W} / \mathrm{F}$ & NONE: & $\mathbf{Y}$ & $N / A$ & & 14.6P'IH3 \\
\hline ME:0328-84 & Gsw & sule: & $37 / W / F$ & NONIZ & $\mathbf{Y}$ & - 0.03 C.X) : METS & $0.09 \mathrm{H} / 13$ & 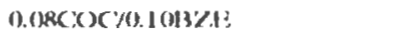 \\
\hline ME(0331 80) & ASE II) & $\mathrm{NAI}$ & $61 / \mathrm{W} / \mathrm{M}$ & NC)NE & $\mathbf{Y}$ & $\mathrm{N} / \mathrm{A}$ & & $N / A$ \\
\hline ME(0341 *') & PHNII) & PI:NI) & $50 / W / F^{2}$ & NCSNL: & $N$ & $N / A$ & & QNS \\
\hline MI:(1345-89 & ()D & stilc: & $G / W / M$ & NONE: & $\mathbf{Y}$ & $N / \Lambda$ & & $3.92 \mathrm{P}^{\mathrm{T}} \mathrm{TH}$ \\
\hline ML:(1346-80) & DIS & $\mathrm{NAT}$ & $52 / \mathrm{W} / \mathrm{M}$ & MINS & $\mathbf{N}$ & $N / A$ & & ONS \\
\hline ME0354. 89 & IN.I & $A C x:$ & $30 / \mathrm{W} / \mathrm{M}$ & NONE & $\mathbf{Y}$ & "I $0 \mathrm{~W}(\mathrm{x}) \mathrm{M}$. & 0.00137 .12 & $20 \mathrm{PTM}$ \\
\hline$M E 30362-89)$ & $P[: N I)$ & PI!NI) & $\mid R / W / M$ & NONE: & $\mathbf{Y}$ & $\mathrm{N} / \mathrm{A}$ & & נונוN \\
\hline$M 1: 0367.84$ & Gisw & IIC)M & $20 /(0) / F$ & NONI: & $\mathbf{Y}$ & $N / A$ & & $N / A$ \\
\hline
\end{tabular}




\begin{tabular}{|c|c|c|c|c|c|c|c|c|c|}
\hline 54 & ME036\&-89 & osw & SUIC & $23 / \mathrm{O} / \mathrm{M}$ & NONE & $\mathbf{Y}$ & \multicolumn{2}{|l|}{$\mathbf{N} / \mathbf{A}$} & N/A \\
\hline 55 & ME0373-89 & DIS & PEND & $46 / W / M$ & NONE: & $\mathbf{Y}$ & \multicolumn{2}{|l|}{ N/A } & 9.7 PI II3 \\
\hline 56 & ME0380-89 & SIDS & PEND & $4 \mathrm{M} / \mathrm{W} / \mathrm{M}$ & NONEZ & $N$ & \multirow{2}{*}{\multicolumn{2}{|c|}{$N / A$}} & $I x / C P M$ \\
\hline & FEBRIUARY & & & & & & & & \\
\hline 57 & ME0395-89 & Gsw & sulc: & $48 / W / M$ & NONE: & $\mathbf{Y}$ & \multicolumn{2}{|l|}{$N / A$} & $\mathrm{~N} / \mathrm{A}$ \\
\hline 58 & MP0413-89 & ALC & NAT & $82 / W / M$ & UINKNOWN & $\mathbf{Y}$ & \multicolumn{2}{|l|}{ NEC; } & $N / A$ \\
\hline 59 & ME0434-89 & $\alpha \cdot r$ & DMVA & $17 / \mathrm{W} / \mathrm{M}$ & $<1.0$ & $\mathbf{Y}$ & \multicolumn{2}{|l|}{ NEGG } & NDD \\
\hline 60 & ME0436-89 & INJ & $\mathrm{ACC}$ & $17 / \mathrm{W} / \mathrm{MO}$ & NONE & $\mathbf{Y}$ & \multicolumn{2}{|l|}{$\mathbf{N} / \mathbf{A}$} & $\mathrm{N} / \mathrm{A}$ \\
\hline 61 & ME0438-89 & ASPX & sulc & $19 / \mathrm{W} / \mathrm{M}$ & NONE & $\mathbf{Y}$ & \multicolumn{2}{|l|}{$\mathbf{N} / \mathbf{A}$} & $\mathrm{N} / \mathrm{A}$ \\
\hline 62 & ME0443-89 & OD & PEND & $31 / W / M$ & NONE & $\mathbf{Y}$ & - O.OS COC METS & 0.27 BZE & NEGCOCNOMUZZE \\
\hline 63 & ME0446-89 & SURG & SURG & $83 / W / F$ & NONE & $\mathbf{Y}$ & \multicolumn{2}{|l|}{$\mathbf{N} / \mathbf{A}$} & $\mathbf{N} / \mathbf{A}$ \\
\hline 64 & ME0452-89 & INJ & ACX: & $32 / W / P$ & NONE & $\mathbf{Y}$ & \multicolumn{2}{|l|}{$\mathbf{N} / \mathbf{A}$} & N/A \\
\hline 65 & MEOA53-80 & INI & $A C C$ & $30 / \mathrm{B} / \mathrm{M}$ & NONB & $\mathbf{Y}$ & -0.02 COCMETS & QOS BZE & CXCAZE \\
\hline 66 & ME0464-89 & PEND & PEND & $42 / W / M$ & NONE & $\mathbf{Y}$ & \multicolumn{2}{|l|}{ N/A } & N/A \\
\hline 67 & ME04R6-89 & INJ & $\mathrm{ACC}$ & $39 / \mathrm{W} / \mathrm{P}$ & NONE & $\mathbf{Y}$ & \multicolumn{2}{|l|}{ NEG } & N/A \\
\hline 68 & MFos $12-89$ & ASHD & $\mathrm{ACX}$ & $51 / W / M$ & NONE & $\mathbf{Y}$ & \multicolumn{2}{|l|}{ NEG } & $N / A$ \\
\hline 69 & ME0534-89 & INJ & ACC & $22 / \mathrm{W} / \mathrm{M}$ & NONE: & $\mathbf{Y}$ & \multicolumn{2}{|l|}{ NEiCj } & Thoritice: \\
\hline 70 & ME0535- & $C{ }^{\prime}$ & $\mathrm{ACC}$ & $56 / W / F$ & NONE: & $\mathbf{Y}$ & \multicolumn{2}{|l|}{$N / A$} & $N / A$ \\
\hline 71 & ME0 $0536-800$ & DROW & stIIC: & $27 / H / M$ & NONE: & 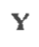 & -0.14 (x) :Ml:'rs & $0.26 \mathrm{~B} / \mathrm{EE}$ & $0.1(x \times)(70.501371:$ \\
\hline 72 & MLOS38-84) & Asp'x & sulk: & $21 / \mathrm{W} / \mathrm{M}$ & NCINE: & $\mathrm{Y}$ & \multicolumn{2}{|l|}{ N/A } & $\mathrm{N} / \mathrm{A}$ \\
\hline 73 & MI:05541-89 & ASHD & NAT & $71 / \mathrm{W} / \mathrm{M}$ & NONI: & $\mathbf{Y}$ & \multicolumn{2}{|l|}{ N/A } & $N / \Lambda$ \\
\hline 74 & $M 1: 0,542-\times)$ & ASt 10 & NAT & $43 / W / M$ & $<1.0$ & Y & \multicolumn{2}{|l|}{$N / \wedge$} & $N / A$ \\
\hline 75 & MI:0545 89 & CCT & PFNIS & $41 / \mathrm{W} / \mathrm{M}$ & 31)AYS & $\mathbf{Y}$ & \multicolumn{2}{|l|}{ NI:C } & $N / A$ \\
\hline 76 & MI:0S4G-84 & Al, : & AIC & $55 / \mathrm{H} / \mathrm{M}$ & NCINE: & $\mathbf{N}$ & \multicolumn{2}{|l|}{$N / A$} & $N / A$ \\
\hline 77 & ME:0:547-89 & sIIUS & PIINI) & $54 / W / M$ & $<1.0$ & $\mathbf{Y}$ & \multicolumn{2}{|l|}{ [ZMHAI MIEI) } & $N / \wedge$ \\
\hline 78 & MF:0548- 89 & IN] & ACC: & $34 / W / M$ & RIJAYS & $Y$ & \multicolumn{2}{|l|}{ BARISS } & 9.(1)' 1113 \\
\hline 79 & ML:0542-8Y & Aș & $N \wedge T$ & $7 \& / W / F$ & NONE: & N & \multicolumn{2}{|l|}{ N/A } & $N / A$ \\
\hline 80 & MI:05501-84 & $\mathrm{Cr}$ & $A C x^{\circ}$ & $3 / 11 / M$ & $<1.0$ & $\mathbf{Y}$ & \multicolumn{2}{|l|}{ NI:C; } & $N / A$ \\
\hline 81 & ME:0S65-89) & ASIID & NA'T & $65 / \mathrm{W} / \mathrm{M}$ & NCINE! & Y & \multicolumn{2}{|l|}{$N / A$} & $N / A$ \\
\hline 82 & ME:0585-8Y & PEND & P'I:NI) & $(x) / W / F$ & NONI: & $\mathbf{Y}$ & \multicolumn{2}{|l|}{$N / A$} & $N / A$ \\
\hline
\end{tabular}




\begin{tabular}{|c|c|c|c|c|c|c|c|c|c|}
\hline 83 & Mitosyz xop & (isw & suk: & $32 / W / M$ & NCSNE & $\mathbf{Y}$ & ONS & ONS & 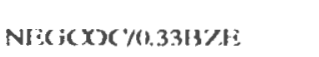 \\
\hline 84 & Mi:05:97 ky & $c x$ & Acx: & $23 / \mathrm{W} / \mathrm{M}$ & $<1.0$ & $\mathrm{Y}$ & $N / A$ & & $N / A$ \\
\hline 85 & 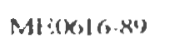 & $(\mathrm{Cr})$ & ACY: & $43 / W / M$ & MINS & $\mathbf{Y}$ & $\mathrm{N} / \mathrm{A}$ & & $\mathrm{N} / \mathrm{A}$ \\
\hline 86 & Ml:1638 $\times 19$ & ASIII) & NAT & $711 / \mathrm{W} / \mathrm{M}$ & NCINI: & $\mathbf{Y}$ & $N / A$ & & $N / A$ \\
\hline 87 & ME:(K,41 Kn) & (isw & Stik: & $(\%) / W / M$ & NONI: & $\mathrm{Y}$ & $N / A$ & & $N / A$ \\
\hline 88 & MI: $(x, 42 \times 12$ & Asm & $\mathrm{NAT}$ & $71 / \mathrm{W} / \mathrm{M}$ & NONIZ & $\mathrm{Y}$ & NI:C; & & $\mathrm{N}(3)$ \\
\hline 89 & Mi:(K47-89) & PIINI) & $P(E N I)$ & $4.5 / W / M$ & Ne)NI: & Y & $N / A$ & & $N / A$ \\
\hline$\varphi()$ & MI:(K,SK Ku) & $(0) 1$ & ACX & $2 x / W / M$ & NONI: & $\mathbf{Y}$ & $N / A$ & & CIIICORIIH:NIRAMINI: \\
\hline 91 & $M F:(x \in(x) s y$ & I)ROWN & AC: & $32 / W / M$ & NONE: & $Y$ & NI:C; & & (.) \\
\hline 92 & MF:(xix,1 $x y$ & $1: x P^{2}(x)$ & $A C x$ & $77 / \mathbf{W} / \mathbf{M}$ & NONI: & $\mathbf{Y}$ & $N / A$ & & $N / A$ \\
\hline 93 & MI:S(KAS3-84) & Dis & NAT & $4.5 / 13 / M$ & LOHRS & $\mathbf{Y}$ & $N / A$ & & $N / A$ \\
\hline 94 & MI:CKases se) & cisw & stuc: & $4 \mathrm{C}_{2} / \mathrm{W} / \mathrm{M}$ & NeNR: & Y & $N / A$ & & (1.27N(J|RI)IAY. \\
\hline 95 & $M E(X, C x) \times(x)$ & IN.I & ACx: & $57 \mathrm{~W} / \mathrm{N}$ & $<21 \mathrm{IlRS}$ & $\mathbf{Y}$ & N/A & & $N / A$ \\
\hline 96 & Mt:(070) - *o) & PI:NI) & ACX: & $3 R / W / M$ & NoINI: & Y & $N / A$ & & $N / \Lambda$ \\
\hline 97 & MI:01010 $\times 9)$ & IN.I & ACX: & $55 / W / 1:$ & $?$ & Y & $N / A$ & & $N / A$ \\
\hline 98 & M1:07(18 89 & AIC & nAt & $0,5 / \mathrm{W} / \mathrm{M}$ & NONE: & $\mathrm{Y}$ & $N / A$ & & 1) XXYIAMINI: \\
\hline 99 & ME:0727 xur & Gisw & sule: & $34 / W / M$ & NONE? & $\mathbf{Y}$ & -0.24 croc.MI:IS & I.(N HZE & $0.07(x)(y)(0)(x) H Z .1$ \\
\hline 100 & Mtso72x xe) & AIC & NAT & $52 / 13 / M$ & 3 JAYS & $\mathrm{Y}$ & NFici & & $N / A$ \\
\hline 101 & ML:0747 א & 1)KOWN & AC: : & $33 / \mathrm{W} / \mathrm{M}$ & N(INE: & $\mathbf{Y}$ & HARISS & & 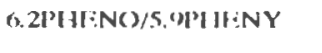 \\
\hline & MARCH 'R" & & & & & & & & \\
\hline 102 & $M 1:(1762-84)$ & Asp'x & ACx: & $\| 1 \mathrm{MC} /() /$ & NoNI: & $\mathbf{N}$ & $N / A$ & & $N / A$ \\
\hline 103 & ME:(070,3-X0) & slitz. & nAT & $24 / W / F$ & NONI: & $Y$ & NISGi & & $6.40: \wedge \mathrm{KH}$ \\
\hline 104 & MI:0701 $\mathbf{X}^{\prime \prime}$ & IN.I & $\wedge c x$ & $70 / W / 15$ & 10DNYS & $\mathbf{Y}$ & NF:C & & $0.42 T O T M C) R$ \\
\hline 105 & $M I \sin 9 \times-x \varphi$ & II:ND & IPEND & $38 \mathrm{WK} / \mathrm{W} /$ & NOJNE: & $\mathbf{N}$ & $N / A$ & & $N / A$ \\
\hline 106 & $M I:(17 \times 6 ; 8)$ & Gsw & INOM & $39 / \mathrm{W} / \mathrm{M}$ & MINS & $Y$ & $N / \wedge$ & & $N / A$ \\
\hline 107 & 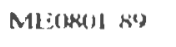 & cisw & IKMM & $23 / 13 / M$ & 10.5 HIRS & $\mathbf{Y}$ & $\mathrm{Ni}:(;$ & & $N / \Lambda$ \\
\hline 108 & MLO(L)14- K') & ASIII) & NAT & $61 / \mathrm{W} / \mathrm{M}$ & NONI: & $\mathbf{Y}$ & NFic; & & $N / A$ \\
\hline 109 & 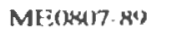 & ASIII) & NAT & $43 / \mathrm{W} / \mathrm{M}$ & NOSI: & $Y$ & $N / A$ & & $N / A$ \\
\hline 110 & Mtases14. Ror & (OD) & PEND & $41 / \mathrm{W} / \mathrm{M}$ & NC)NI? & $\mathbf{Y}$ & - 1.08 CXC:ME'TS & $1.29 \mathrm{BZE}$ & 1.97CXC/1.5213:1: \\
\hline 111 & MF:08820-81\% & (II) & PISND & $2(\mathrm{M} / \mathrm{W} / \mathrm{M}$ & 36 HIRS & $\mathbf{Y}$ & $-0.26(x)$ CML:1S & $1.16 \mathrm{~B} / \mathrm{H} \mathrm{E}$ & $0.0 \cos \times x \times(1.291371$ \\
\hline
\end{tabular}




\begin{tabular}{|c|c|c|c|c|c|c|c|c|c|}
\hline 112 & $M 1:(1) 22 \times 1)$ & Asi'x & silk. & $20 /(2) / M$ & 2 HIRS & $\mathrm{Y}$ & $N / A$ & & I.II)/1111:NY \\
\hline 113 & ME:ONe(13-S4) & (o) & Acr & $M M C / W / M$ & NONI: & Y & QNS & & N()1) \\
\hline 114 & MI:(OSKS, X') & INJ & stike & $3.4 / W / M$ & $0.51112 \mathrm{~s}$ & $\mathrm{Y}$ & $N / A$ & & 10.0AMOBЗARIBITAI. \\
\hline 115 & MI:OKS7x sc, & ()I & UNC'I ASS & $2(1 / W / M$ & MOIDAYS & r & $=0.03(x)$ MI:Ts & 0.03137 .13 & 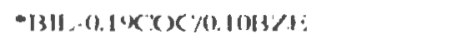 \\
\hline 116 & $M E:(18 \times(2)-x)^{\prime}$ & IN.I & sco & $s \mathrm{~s} / \mathrm{w} / \mathrm{i}$ & 10 MINS. & $\mathrm{Y}$ & $N / A$ & & NIJ) \\
\hline 117 & 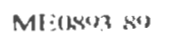 & DROWN & AC & $N 2 / W / M$ & NC)NI: & $\mathrm{Y}$ & $N / A$ & & NIM \\
\hline 118 & Mi:(1Kus R') & $\mathrm{ccos}^{2}$ & ACr. & $19 / \mathrm{W} / \mathrm{M}$ & NoNi: & $\mathrm{Y}$ & $N / A$ & & NiA \\
\hline 119 & Mit:(Kx|s $\left.x^{\prime \prime}\right)$ & $c r \cdot T$ & ACs & $73 / \mathrm{W} / \mathrm{N}:$ & NoSN: & Y & OPATTS & &  \\
\hline 120) & $\left.M \mathrm{Ml}(\boldsymbol{\alpha}) 12 \mathrm{x}^{4}\right)$ & PI:NI) & II:NIJ &, $77 / 13 / \mathrm{M}$ & NONE: & N & $N / A$ & & 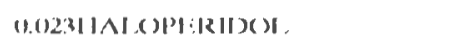 \\
\hline 121 & MI:(K)13-80) & PIINI) & PIINI) & $75 / \mathrm{W} / \mathrm{A}:$ & NONI: & Y & $N / A$ & & $N / A$ \\
\hline 122 & ML:(r)22 $\times 4$ & $\operatorname{sis} x$ & Ac $C^{\circ}$ & $1.3 \mathrm{M}(3 / \mathrm{W} /$ & NoNI: & Y & $N / \Lambda$ & & NIOI) \\
\hline 123 & $M F:(K, 39) \times 4)$ & DROWN & ACr & $24 / \mathrm{W} / \mathrm{M}$ & NOSNE: & Y & $N / \Lambda$ & & $N / A$ \\
\hline 124 & $M I:(K \times 40) \times()$ & DROWN & stilc & $S \mathrm{~s} / \mathrm{W} / \mathrm{M}$ & NOSI: & Y & $\mathrm{Nl} \cdot \mathrm{c} ;$ & & 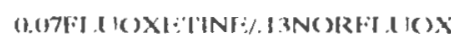 \\
\hline 125 & ME:(KM:5-x") & IIINI) & PIINI) & $31 / 13 / M$ & NoNi: & Y & Nis & & $N / A$ \\
\hline 126 & 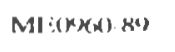 & As(II) & $\operatorname{sic}$ & $41 / W / M$ & NONI: & Y & $N / A$ & & $N(1)$ \\
\hline 127 & $M 1:\left(x x_{3} 5 \cdot 8,4\right.$ & ASIM & PINNI & $3 \mathrm{~S} / \mathrm{W} / \mathrm{M}$ & NONE? & $\mathrm{Y}$ & -0.05 (O):ME'IS & $1.29137 \mathrm{~K} ?$ & $0.11(x)(0.7213 / 2 \mathrm{t}$ \\
\hline 128 & 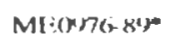 & (I) & PIINI) & $1 \% / W / M$ & NCONE: & $\mathrm{Y}$ & $\cdot 0.03$ c COC.MHTS & 0.01 HZJ & 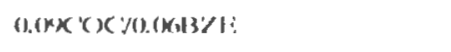 \\
\hline 129 & Mr:(K)\&3-R9 & $\operatorname{Asp} x$ & stike & $22: \mathrm{W} / \mathrm{M}$ & NONI: & Y & $N / s$ & & $N / A$ \\
\hline 130 & Ml:(x)85-84 & $\mathrm{coT}$ & Ac $x^{\circ}$ & $34 / W / l$ & > PIIRS & $\mathrm{Y}$ & Ni:G & & $N / A$ \\
\hline 131 & M1:orss, k' & CrT & ACr. & $64 / W / F$ & NeINI: & $\mathrm{Y}$ & $N / \Lambda$ & & $N / A$ \\
\hline 132 & $\left.M I^{\prime}(1 \times x), x^{\prime \prime}\right)$ & IJROWN & Acr. & W/W/M & N(INI: & $\mathrm{Y}$ & $N / A$ & & $N: A$ \\
\hline 133 & $M 1:(x \times) 7 x$ & DKOWN & 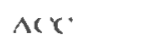 & $11 / M / W$ & NOSI: & Y & $N / A$ & & $N / A$ \\
\hline 134 & NII:I(K)1 K9 & $\operatorname{Asp} x$ & sec & $\mathrm{X} 11 / \mathrm{W} / \mathrm{M}$ & MINS & Y & NI:Si & & NIM \\
\hline 135 & M(IIX)S x') & (c) & Ace & $\mathrm{KS} / \mathrm{W} / \mathrm{M}$ & IAYS & $\mathrm{N}$ & $N / A$ & & $N / \Lambda$ \\
\hline 136 & MI:1615 אי & AIC: & NAT & $45 / 13 / \mathrm{M}$ & NCONI: & $\mathrm{Y}$ & $N / A$ & & 0.0ISAI PRARAOIAM \\
\hline 137 & Mt:1(120) $\left.x^{4}\right)$ & ASIII) & Ac' & $51 / / \mathrm{W} / \mathrm{M}$ & NCONI: & $\mathrm{Y}$ & $N / A$ & & $\mathrm{~N}()$ \\
\hline 138 & ME:I(IAI-81\% & PIINI) & PIINI) & $31 \mathrm{Wk} / \mathrm{W} /$ & NeNA: & $\mathrm{r}$ & "ONS & oNS & 0. $30 x^{\prime}(x) / 1.121381:$ \\
\hline 1.39 & MLIICA2 X' & Gsw & WM & $17 / \mathrm{W} / \mathrm{M}$ & MINS & $\gamma$ & $N / A$ & & 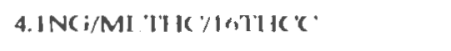 \\
\hline 140 & ML:I(147 89$)$ & IN. & Acx: & $2 \mathrm{R} / 1 \mathrm{13} / \mathrm{M}$ & NONI: & $\mathrm{Y}$ & N/A & & $N / A$ \\
\hline 141 & M1:11151 $\mathrm{kn}$ & ASIII) & NAT & $0,3 / 13 / M$ & NeSNE: & $\gamma$ & $N / A$ & & $N / A$ \\
\hline
\end{tabular}




\begin{tabular}{|c|c|c|c|c|c|c|c|c|c|}
\hline 142 & ME1056-89 & AS'TM & NAT & $23 / W / M$ & NONE & $\mathbf{Y}$ & N/A & & 2.2THECSPHYYLIINI: \\
\hline 143 & ME1062-89 & PEND & PEND & $20 / \mathrm{W} / \mathrm{M}$ & 42HIRS & $\mathbf{N}$ & $N / A$ & & 1.8CARI3AMAZIIPINE \\
\hline 144 & ME1066-89 & PEND & PENI) & $4 M() / W / F$ & NONE & $\mathbf{Y}$ & NIBG & & N/A \\
\hline 145 & ME1070-89 & GSW & HOM & $17 / 8 / M$ & 2 DAYS & $\mathbf{Y}$ & NEG & & 7.8PIIENYTIOIN \\
\hline 146 & ME1090-89" & CCT & $\mathrm{AOC}$ & $19 / \mathrm{N} / \mathrm{M}$ & $<1 \mathrm{HR}$ & $\mathbf{Y}$ & -0.11 COCMMETS & $0.17 \mathrm{BZE}$ & $0.08 C O C J 0.24132 \mathrm{E}:$ \\
\hline 147 & ME1091-89 & COI & ACC & $50 / 3 / M$ & NONE & $\mathbf{Y}$ & NEG & & $N / A$ \\
\hline 148 & ME1098-89 & DIS & NAT & $31 / \mathrm{W} / \mathrm{F}$ & NONE & $\mathbf{Y}$ & NEG & & I IDOCAINE \\
\hline 149 & ME1097-89 & DIS & PEND & $47 / \mathrm{W} / \mathrm{M}$ & NONE & $\mathbf{Y}$ & N/A & & N/A \\
\hline 150 & ME1104-89 & PEND & PEND & $25 / W / M$ & NONE & $\mathbf{Y}$ & NEG & & AC.ETONE/ISOPROPYL \\
\hline 151 & ME1128-89 & IN J & $A O C$ & $44 / \mathrm{W} / \mathrm{M}$ & 6DAYS & $\mathbf{Y}$ & $\mathbf{N} / \mathbf{A}$ & & NDD \\
\hline 152 & ME1145-89 & Gsw & SUIC & $19 / W / F$ & NONE & $\mathbf{Y}$ & N/A & & LIDOCAINE \\
\hline 153 & ME1150-89 & Dis & NAT & GMONW/F & NONE & $\mathbf{Y}$ & $\mathbf{N} / \mathbf{A}$ & & ONS \\
\hline 154 & ME1142-89 & ASHD & NAT & $85 / W / F$ & NONE & $\mathbf{N}$ & N/A & & ACETONE \\
\hline 155 & ME1162-89 & ASHD & NAT & $53 / W / F$ & NONE & $\mathbf{Y}$ & NEO & & 0.13 VERAPAMIL \\
\hline 156 & ME1165-89 & $O D$ & PEND & S4/W/F & NONE & $\mathbf{Y}$ & OPIATES & & 0.45FRLECOD/1.5TOTCOD \\
\hline 157 & ME1086-89 & AlC & NAT & $48 / W / M$ & NONE & $\mathbf{N}$ & N/A & & NDD \\
\hline & April 89 & & & & & & & & \\
\hline 158 & ME117(28) & $\mathrm{CO1}$ & $A(x)$ & $S \varphi / W / M$ & NONE & $\mathbf{Y}$ & N/A & & $44.8 \% 1+13(\gamma)$ \\
\hline 159 & ME:1177-\&3 & $(x) 1$ & $A C x:$ & $49 / \mathrm{W} / \mathrm{M}$ & NCNL: & $\mathbf{Y}$ & $\mathbf{N} / \mathbf{A}$ & & $46 .(5 \%, 1] 13(x)$ \\
\hline 160 & ME1185-84 & OD & IINCTASS & $51 / \mathrm{W} / \mathrm{M}$ & $4 \mathrm{HKS}$ & $\mathbf{Y}$ & $\mathbf{N} / \mathbf{A}$ & & N/A \\
\hline 161 & ME1186.8\% & $O D$ & UNCIASS & $24 / W / M$ & NONE & $\mathbf{Y}$ & -0.98 CXC:MHETS & $0.54 \mathrm{~B} / \mathrm{H} \mathrm{H}$ & $0.07(x)(0.5613 \% 15$ \\
\hline 162 & ME:1190-89 & $\mathbf{I N} \mathbf{I}$ & $\Delta C x$ & $1 \mathrm{k} / \mathrm{W} / \mathrm{M}$ & $<111 R$ & $\mathbf{Y}$ & $\mathrm{N} / \mathrm{A}$ & & $N / A$ \\
\hline 163 & ME:1210-\$9 & ASIII) & NAT & $(x) / W / M$ & NONES & $\mathbf{Y}$ & N/A & & $N / A$ \\
\hline 164 & $M\left(1211-R^{4}\right)$ & Al.c: & NAT & $84 / W / M$ & NC)NE & $\mathbf{Y}$ & NIBG & & NIDE \\
\hline 165 & MI:1226-89 & INJ & $A C x:$ & $74 / \mathrm{W} / \mathrm{M}$ & NONE? & $\mathbf{Y}$ & NIag & & I.II)OCAINI: \\
\hline 166 & ME1 228-84) & INJ & $A C X$ & $41 / \mathrm{W} / \mathrm{M}$ & NONE: & $\mathbf{Y}$ & NFi: & & $N / A$ \\
\hline 167 & ME12204.8\% & ASPX & HC)M & $201 / 3 / M$ & NONI? & $\mathbf{Y}$ & $=0.23$ (X):ME:IS & $0.24 \mathrm{BVtl}$ & $0.1(<\times) \times 10.1313 / 1 !$ \\
\hline 168 & MF:123389 & AI $C:$ & NAT & $45 /() / M$ & NONI: & $\mathbf{Y}$ & NIJG & & I.II)C(AINI:/OUININI: \\
\hline 169 & ME1246-89 & A.sPX & sule: & $17 / 3 / M$ & NONE: & $\mathbf{Y}$ & $\mathrm{NIBO}$ & & (DOOTHIICKIIDAZINE? \\
\hline 170 & ME125(1)-89 & ASHID & NAT & $71 / \mathrm{W} / \mathrm{M}$ & NONE: & $\mathbf{Y}$ & NFG & & $N / A$ \\
\hline
\end{tabular}




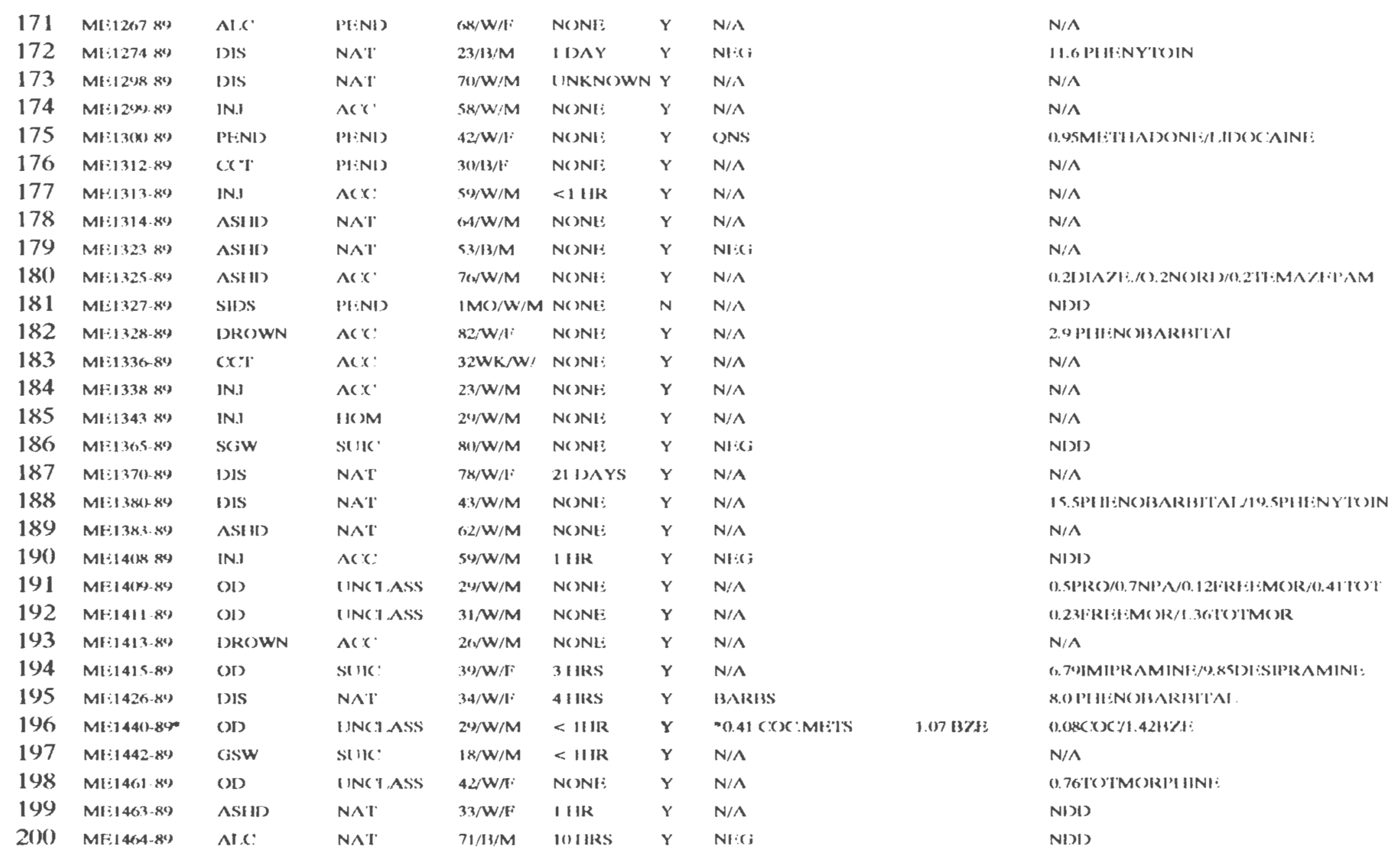




\begin{tabular}{|c|c|c|c|c|c|c|c|c|c|}
\hline 201 & ME1473-89 & SIDS & PENI & $2.5 \mathrm{MO} / \mathrm{W} /$ & NONE & $\mathbf{N}$ & N/A & & NDD \\
\hline 202 & ME1491-89 & $\propto T$ & $A C C$ & $20 / \mathrm{W} / \mathrm{M}$ & $>4.5 \mathrm{DAYS}$ & $\mathbf{N}$ & $N / A$ & & $\mathbf{N} / \mathbf{A}$ \\
\hline 203 & ME1497-890 & PEND & PEND & 6WK/W/M & NONE & $\mathbf{Y}$ & -0.02 COCMETS & QNS & 0.0RCOCNNECIBZE: \\
\hline 204 & ME1 S05-89 & ASPX & ACr. & $57 / \mathrm{W} / \mathrm{M}$ & NONH: & $\mathbf{Y}$ & $N / A$ & & O.3NOR'TR IP'TYLINE \\
\hline 205 & MP1506-89 & SIDs & PEND & $2 M O / W / M$ & NONE: & $\mathbf{Y}$ & ONS & & QNS \\
\hline 206 & ME1507-89 & GSW & HOM & $49 / \mathrm{W} / \mathrm{F}$ & NONE? & $\mathbf{Y}$ & N/A & & N/A \\
\hline 207 & ME1508-89 & Gsw & suic. & $47 / \mathrm{W} / \mathrm{M}$ & NONE & $\mathbf{Y}$ & NEG & & NDD \\
\hline 208 & ME1511-89 & ALC & UNCTASS & $34 / W / M$ & NONE & $\mathbf{Y}$ & $N / A$ & & N/A \\
\hline 209 & ME1512-89 & GSw & HOM & $27 / \mathrm{W} / \mathrm{M}$ & NONE & $\mathbf{Y}$ & -0.33 COC.METS & $0.39 \mathrm{BZE}$ & $0.15 C O K / 0.451371$ \\
\hline 210 & ME1513-89 & PEND & $\mathrm{ACC}$. & $16 / W / M$ & 3 DAYS & $\mathbf{Y}$ & $N / A$ & & QNS \\
\hline 211 & ME1 $530-80$ & asw & HOM & 23/B/M & a.S HR & $\mathbf{x}$ & - 1.29 COCMETS & $2 \pi$ Bze & $0.0900 \mathrm{C} 203132 \mathrm{E}$ \\
\hline 212 & ME1547-89 & Gsw & ном & $22 \pi \mathrm{W} / \mathrm{M}$ & NONE & $\mathbf{Y}$ & NEG & & NDD \\
\hline 213 & ME1548-89 & OD & UNCLASS & $14 / W / F$ & NONE & $\mathbf{Y}$ & $\mathbf{N} / \mathbf{A}$ & & 1.7AMITRIPTYI.INE/2.2NORTRIP. \\
\hline 214 & ME1555-89 & CVA & NAT & 59/W/F & NONE & $\mathbf{Y}$ & NEG & & NDD \\
\hline 215 & Me1557-890 & ANEU & NAT & $29 / W / M$ & $<1 \mathrm{HR}$ & $\mathbf{r}$ & 0.02 OXXCMETS & $0.02 \mathrm{BzF}$ & O.OMOTMOR,/O.MFFRPCOD/0.24TOT. \\
\hline 216 & $M{ }^{15} 1567=89$ & INJ & $\mathrm{ACC}$ & $3 / \mathrm{W} / \mathrm{M}$ & NONI? & $\mathbf{Y}$ & NIJG & & $N / A$ \\
\hline 217 & ME1571-84* & $\cos r$ & ACX: & $25 / \mathrm{W} / \mathrm{M}$ & NONE: & $\mathbf{Y}$ & - 0.03 cor.Mr:Is & $0.49137 \mathrm{E}$ & 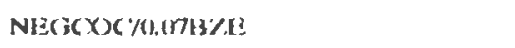 \\
\hline 218 & MI:1572-89) & IN.I & ACC: & $18 / \mathrm{W} / \mathrm{t}$ & SI AAYS & $\mathbf{Y}$ & $N / A$ & & (1.0BI)IAZI:PAM $/<0.01 N($ NRI)IA /IPAM \\
\hline 219 & $M I: 16(1)-80$ & Gisw & stike & $53 / W / M$ & NONF: & $\mathbf{Y}$ & $N / A$ & & $N / A$ \\
\hline 220 & ME1615-89 & Gsw & SUIC: & $32 / \mathrm{W} / \mathrm{M}$ & Ne)NI? & $\mathbf{Y}$ & $N / A$ & & $N / A$ \\
\hline 221 & MHilex19.89 & P(ENI) & PIENI) & $71 / \mathrm{W} / \mathrm{k}$ & $<\mathbf{H} H R$ & $\mathbf{Y}$ & BARISS & & 13.0 M(Xi/MI, IPII:N() \\
\hline 222 & ME: $1613-89$ & IN.J & MVA & $86 / 1 / 1:$ & MINS & $\mathbf{Y}$ & NISC; & & DL:X'ROMI:IIURIPIIAN \\
\hline 223 & ME1616-89 & INJ & $A C X$ & $31 / \mathrm{W} / \mathrm{M}$ & <IIIR & $\mathbf{Y}$ & $\mathrm{N} / \mathrm{A}$ & & $\mathbf{N} / \mathbf{A}$ \\
\hline 224 & MF: $1626-N 9$ & AsIII & NAT & $52 / \mathrm{W} / \mathrm{M}$ & NoINE: & $\mathbf{Y}$ & NISG & & 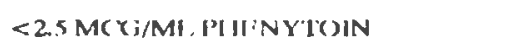 \\
\hline 225 & MI: $1633 \mathrm{Kg}$ & IN.I & MVA & $72 / \mathrm{W} / \mathrm{M}$ & NONI? & $\mathbf{Y}$ & $N / A$ & & $N / A$ \\
\hline 226 & ME:1648-89 & IN.I & ACC: & $22 / \mathrm{W} / \mathrm{M}$ & MINS & $\mathrm{Y}$ & $\mathrm{N} / \mathrm{A}$ & & NIDD \\
\hline 227 & ME: $1650-89$ & Asp'x & sinc & $17 / \mathrm{W} / \mathrm{M}$ & MINS & $\mathrm{Y}$ & $\mathrm{NL}: \mathrm{G}$ & & I.IIOOCAINE: \\
\hline 228 & MI:1653.89n & $(D)$ & sule: & $40 / \mathrm{H} 3 / \mathrm{F}$ & NONE: & $\mathbf{Y}$ & -0.10CXOC.ML:TS & $0.21 \mathrm{HZCE}$ & NIJC; $(O O C /() .14137 \mid 1 /(1.7 \mid P R O P$ \\
\hline 229 & ME1605.80" & [PENI) & PENI) & $42 \mathrm{~W} / \mathrm{M}$ & NONE & $\mathbf{Y}$ & $\bullet 0,01$ (X)C.MI:TS & $0 .(X)$ BZZE & $\mathbf{N} / \mathbf{A}$ \\
\hline 230 & Misicho Ko & IN.I & MVA & $24 / W / E:$ & $2.511 \mathrm{KS}$ & $\mathbf{Y}$ & $N / A$ & & N/A \\
\hline
\end{tabular}




\begin{tabular}{|c|c|c|c|c|c|c|c|c|c|}
\hline 231 & ML: 1 (16, 80 & Gisw & Stik: & $41 / \mathrm{W} / \mathrm{M}$ & N()NI: & $\mathbf{Y}$ & $N / \wedge$ & & $N / A$ \\
\hline 232 & M1:1671 K2 & ASIII) & $\mathrm{NAI}$ & $57 / \mathrm{W} / \mathrm{M}$ & NONI: & $\mathbf{Y}$ & $N / A$ & & $N / A$ \\
\hline 233 & M\&:16070-890 & IN.J & IKMM & $20 / W / 1$ & NONI? & $\mathbf{Y}$ & -0.24 COC:ME'1S & $0.31 \mathrm{BZ} Z \mathrm{E}$ & $0.62(x)(70.76137 / 1:$ \\
\hline 234 & MI:I $1087-89$ & DIS & NAI & $67 / \mathrm{W} / \mathrm{M}$ & NENE: & $\mathrm{Y}$ & $\mathrm{NI}:(;$ & & 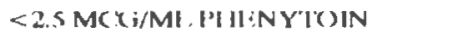 \\
\hline 235 & ME:1692-49 & IN.I & $116) \mathrm{M}$ & $53 / \mathrm{W} / \mathrm{M}$ & NONr: & $\mathbf{Y}$ & $N / A$ & & (9.3M('(I/MI . PIII:NO) \\
\hline 236 & Mliss(6) 89 & ANI:A & NAT & $37 / \mathrm{W} / \mathrm{M}$ & NONI: & $\mathbf{Y}$ & $N / A$ & & $N / A$ \\
\hline 237 & Mi:1697.89 & IN.I & $A C C^{\circ}$ & $5 \mathrm{~N} / \mathrm{W} / \mathrm{M}$ & NeINI: & $\mathbf{Y}$ & NI:C; & & 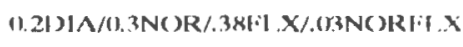 \\
\hline 238 & $M 11: 1710=8^{4}$ & IN.I & ACr: & $2 / \mathbf{W} / \mathbf{F}$ & NONIS & $\mathrm{Y}$ & $N / A$ & & $N / A$ \\
\hline 239 & ME:1713-8") & (OI) & $\wedge C^{\prime}{ }^{\circ}$ & $26 / W / F$ & NOSI: & $\mathrm{Y}$ & $N / \wedge$ & & 1.SI'R()/1.1NPA/.376 'YCIC()IBH:NZ. \\
\hline 240 & $M(: 1714-89$ & IN.I & $110 \mathrm{M}$ & $3.5 / 13 / 1 ;$ & NONI: & $\mathbf{Y}$ & $N / A$ & & 14.81 1'II:N() \\
\hline 241 & Ml:1719-89 & IN.J & $\wedge C x:$ & $41, \mathrm{~W} / \mathrm{M}$ & NONI: & $\mathrm{Y}$ & $N / A$ & & $N / A$ \\
\hline 242 & MF:1741-89 & IN.I & MVA & $34 / W / M$ & IIR & $\mathrm{Y}$ & NI?; & & III)(XINI? \\
\hline 243 & MI:1743-89 & ck:y & MVA & $21 / \mathrm{W} / \mathrm{M}$ & 30 IIRS & $\mathbf{Y}$ & $\mathbf{N} / \mathbf{A}$ & & NIJD \\
\hline 244 & ML:1745 89 & Aspx & stuk: & $16 / W / M$ & NeNI: & $\mathrm{Y}$ & NISG & & NI) \\
\hline 245 & M(:175,3-89) & IN.I & MVA & $21 / \mathrm{W} / \mathrm{M}$ & N()NI: & $\mathbf{Y}$ & $N / A$ & & $N / A$ \\
\hline 246 & MF:1754-k9) & AsIII) & $\mathrm{N} \wedge \mathrm{T}$ & $4.5 / \mathrm{W} / \mathrm{M}$ & NONE! & $\mathbf{Y}$ & $N / A$ & & $N / \Lambda$ \\
\hline 247 & ME:17841-89 & NIC: & NAI & $S\left(L_{1} / \mathbf{W} / \mathbf{M}\right.$ & MOSNI: & $\mathbf{Y}$ & $N / A$ & & $N / A$ \\
\hline 248 & $M[118011-89$ & Gisw & $110 \mathrm{M}$ & $S N / W / M$ & $1 \mathrm{IIR}$ & $\mathbf{Y}$ & $N / \wedge$ & & $N / \Lambda$ \\
\hline 249 & $M E: 1811-R^{4}$ & IN. 1 & MV^ & $39 / \mathrm{W} / \mathrm{M}$ & NOINI: & $\mathbf{Y}$ & $=0.85$ CXC:ME'Ts & $0.41 \mathrm{BZ} / \mathrm{X}$ & $0.42 \mathrm{H} / \mathrm{E} / \mathrm{NI}: \mathrm{C}(x) \mathrm{x}$ \\
\hline 250 & MF:1812-89\% & IN. & MVA & $29 / W / F$ & NONI? & $\mathbf{Y}$ & -0.33 COC:MHIS & $0.57 \mathrm{HBJ}$ & $0.2513 \%, E$ : \\
\hline 251 & Mi:1\$22 84 & PI:NI) & PI:NI) & I $M / 13 / M$ & NONE: & $Y$ & $N / A$ & & ONS \\
\hline 252 & $M F: 1 \times 25 \cdot 84$ & Dis & $\mathrm{N} \wedge \mathrm{T}$ & $4 \% / W / M$ & XHIRS & $\mathbf{Y}$ & $N / A$ & & $N / A$ \\
\hline 253 & Mli1X2n-84 & $\cos$ & MVA & $16 / W / F$ & NC)NI: & $\mathbf{Y}$ & $N / A$ & & $N / A$ \\
\hline 254 & Mli1820 K9 & $(x)$ & AC. & $36 / W / M$ & N()NI: & $\mathrm{Y}$ & $N / A$ & & $N / A$ \\
\hline 255 & $M F 1 \times 34-89$ & DIS & $\mathrm{N} \wedge \mathrm{T}$ & $47 / \mathrm{W} / \mathrm{M}$ & $1 \mathrm{HIR}$ & $\mathbf{Y}$ & NEG; & & 0.1 lifi $\mathrm{X} / 0.14 \mathrm{~N} \mid \mathrm{X} / 0.21) 1 \mathrm{~A}$ \\
\hline 256 & ME1S34 84 & OI) & I JNCX, & $33 / \mathrm{W} / \mathrm{M}$ & NoNE: & $\mathbf{Y}$ & -1.us COC:Mlits & $1.02 \mathrm{BZE}$ & $3 . \operatorname{cx}(x)(2 / 2191377:$ \\
\hline 257 & $M(: 183(9-89)$ & IN.J & MVA & $31 / W / M$ & $1 \mathrm{IIR}$ & $\mathbf{Y}$ & $N / A$ & & $N(3)$ \\
\hline 258 & $M t: 1841-89$ & Gsw & $116 \mathrm{M}$ & $62 \mathrm{~W} / \mathrm{t}^{\mathrm{i}}$ & NONI? & $N$ & $N / \wedge$ & & $0.0 N() R D I \wedge \% 1 \mathrm{P} A M$ \\
\hline 259 & Mt:185:-840 & ASPX & sulc: & $42 / 13 / M$ & NONIE & $\mathbf{Y}$ & - 1.01 COC.ME'IS & $0.5813 \% 11$ & $0.0 \times \times \times)(70.5313 / 78$ \\
\hline 260 & ME:1856 84 & Gsw & HOM & $35 / 13 / M$ & 1.5 IIRS & $\mathbf{Y}$ & NEiGi & & $1.11)(x)(A I N E$ \\
\hline
\end{tabular}


JUNE 1989

\begin{tabular}{|c|c|c|c|c|c|}
\hline 261 & MF:1864-89 & EIdBC & $A C X$ & $30 / \mathrm{W} / \mathrm{M}$ & NONE \\
\hline 262 & ME1899-8\% & Gisw & HOM & $32 / 1 / M$ & 1.5 HRS \\
\hline 263 & ME19M-89" & IVDA & UNCT A & $27 / \mathrm{W} / \mathrm{M}$ & NONE: \\
\hline 264 & ME1905-89 & ASHI) & NAT & $36 / W / M$ & MINS \\
\hline 265 & ME1908-89 & $\alpha=1$ & $A C C$ & $4 \& / \mathrm{W} / \mathrm{M}$ & NONE \\
\hline 266 & ME1935-89 & INJ & sulc. & $25 / W / M$ & MINS \\
\hline 6 & ME1948-89 & Cor & IIOM & $45 / W / M$ & NONE \\
\hline 68 & ME1952-89 & $\alpha r$ & $A C X$ & $60 / W / M$ & $1 \mathrm{WK}$ \\
\hline 69 & ME1953-89 & ASHD & NAT & $41 / \mathrm{W} / \mathrm{M}$ & NONE \\
\hline 70 & ME1970-89 & INJ & $A C C$ & $34 / \mathrm{W} / \mathrm{M}$ & NONE \\
\hline 11 & ME1981-89 & DIS & NAT & $2 \mathrm{WW} / \mathrm{M}$ & NONE \\
\hline 72 & ME1985-89 & ASHD & NAT & GANW/M & NONE \\
\hline 2 & ME1991-890 & $\alpha T$ & MVA & 3QMAP & NONE \\
\hline & ME1995-89 & DIS & NAT & $21 / W / M$ & NONE \\
\hline 75 & ME2012-89 & PLEND & PEND & Sorw/M & GIIRS \\
\hline 76 & Mt:2162-89 & INJ & MVA & $24 / W / M$ & NONE: \\
\hline 2 & ML:2164 89 & ASI HD & NA'I & $31 / \mathrm{W} / \mathrm{M}$ & MINS \\
\hline 78 & ML:21(xorsis) & DIS & NAT & $63 / \mathrm{W} / \mathrm{M}$ & $1 \mathrm{HK}$. \\
\hline 79 & Me2171-89) & ASPX & stilc & $25 / 13 / M$ & NONE \\
\hline 80 & ME2193-89 & $c x+1$ & ACX: & $81 / W / 4$ & 9DAYS \\
\hline & ML:2215-K9 & IN.J & $A C: C^{\circ}$ & $7.5 / W / M$ & 25 I A YS \\
\hline & $M(: 20(13-89)$ & StIIDS & PIIND & $50 / W / M$ & NONE: \\
\hline 284 & Mk:2005-xir & OD & UNCI ASS & $31 / \mathrm{W} / \mathrm{i}$ & NONE \\
\hline & ML:201099-800 & Gsw & sule. & $21 / W / M$ & NONE: \\
\hline & $M E: 20(x, 80)$ & IN.I & $A C x:$ & $21 / \mathrm{W} / \mathrm{M}$ & NONE \\
\hline & ME:2014-8Y & OID & AsPX & $37 / \mathrm{W} / \mathrm{M}$ & NONE: \\
\hline & $M E: 2(123-84)$ & ASI HD & NAT & $G / N / M$ & NONE? \\
\hline & MI320127-xu & Aspx & suic & $28 / \mathrm{W} / \mathrm{M}$ & NON: \\
\hline & MF:20139.8D & AsIII) & NAT & $72 / W / 1 i$ & NONH: \\
\hline
\end{tabular}

$\mathbf{N} / \mathbf{A}$

- 0.52 COCEMEIS

-2.59 COC.METS

N/A

N/A

-1.38 COCMETS 0.83 BZE

N/A

N/A

N/A

N/A

N/A

N/A

- asi COCMETS

BARBS

N/A

N/A

N/A

Ni:C;

N/A

Ni:Ci

NI:G

N/A

- 0.cor cos:mets

*0.50 coc.mets

N/A

N/A

NiA



$\mathrm{N} / \mathrm{A}$

a.65 BZF
N/A

$0.22 C 0)(0.4737 .1$,

$0.11 \mathrm{COC} 0.7713 \mathrm{YE}$

N/A

N/A

0.16COCC/0.82BZE

N/A

N/A

N/A

N/A

N/A

$0.17 \mathrm{COC} / 0.71 \mathrm{BZE}$

NIDD

23.0 TI IFIOPIIYI IJINE

N/A

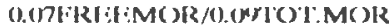

Ni)

NIDI)

NI)

NiA

$14.75(x)\left(\frac{14.5213 \% \mathrm{E}}{}\right.$

NIEGiCO) INASGIJZI?

NiA

$\mathrm{N} / \mathrm{A}$

N/A

$0.216)(\%) .3313 \%$

$\mathrm{N} / \mathrm{A}$ 


\begin{tabular}{|c|c|c|c|c|c|c|c|}
\hline 1 & $M 1 \cdot 2052 \times 4$ & CisW & HIOM & $\mid \omega / \mathrm{W} / \mathrm{t}$ & N()NI: & $N$ & $N / \Lambda$ \\
\hline 292 & MI:2014 & sil & {$[1(N)$} & (WVK/()/F & NCINI: & $N$ & $N / \wedge$ \\
\hline 93 & Milizoso & DRow & $A C x^{\circ}$ & $02 / 11 / M$ & NONI' & $Y$ & NI:K; \\
\hline (9.4 & MI:20157. k" & (c) $\mathrm{C}$ & $A C C^{\circ}$ & 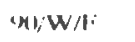 & 4 IIIRS & $Y$ & $\mathrm{~N} i \Lambda$ \\
\hline 95 & $M 1: 2\left(k_{1} 2-k^{\prime \prime}\right)$ & AsIII) & NAT & $32 / \mathrm{W} / \mathrm{t}$ & IK) & $Y$ & $N / A$ \\
\hline 66 & $M 1 \cdot 2(172 \times)$ & AsIII) & $\mathrm{NAl}$ & $7.1 / \mathrm{W} / \mathrm{M}$ & NC)NI: & $r$ & $N / A$ \\
\hline 97 & Mi:20174 & morow & Acr. & $13 / \mathrm{W} / \mathrm{M}$ & NONI: & $\gamma$ & $N / \Lambda$ \\
\hline 98 & $M 1: 20187 \times 4$ & $68 \%$ & $A C$ & $I r / W / M$ & Ne JNI: & $Y$ & $\mathrm{~N} / \mathrm{A}$ \\
\hline 9 & $M !: 2111 \mathrm{kn}$ & ()1) & AC $x^{\circ}$ & $35 / W / M$ & NoNI: & $r$ & NiA \\
\hline 300 & $\left.M B^{\prime}=2 I(K) K^{\prime \prime}\right)$ & IDS & $\mathrm{NAl}$ & $1,1 / 13 / 1$ & NeINI: & $Y$ & $\mathrm{~N}$ iN \\
\hline () 1 & M1:21:3 & (II) & $\wedge C^{\prime} \mathrm{C}:$ & $3 \mathrm{~S} / \mathrm{W} / \mathrm{K}$ & NOINI: & $\mathrm{Y}$ & $N / \Lambda$ \\
\hline 12 & M1:2117 Ko & PIINI) & {$\left[1 \mid N_{1}\right)$} & $S \mathrm{~A} / \mathrm{W} / \mathrm{M}$ & Ne JNI: & $Y$ & $N / A$ \\
\hline 30.3 & $\left.M 1: 212 n x^{4}\right)$ & DIR()W & AC $C^{\circ}$ & $3 K / W / M$ & NCUNI: & $Y$ & $N / \Lambda$ \\
\hline 304 & $M 1: 2132 \times 41$ & $10120 \mathrm{~W}$ & AC ${ }^{\circ}$ & $62 / 13 / M$ & NONI: & $N$ & $\mathrm{~N} / \mathrm{A}$ \\
\hline & $M 1: 2136 \times 4)$ & $\mathrm{CC}^{\circ} \mathrm{C}$ & MVA & $\because 2 \mathrm{~W} / \mathrm{M}$ & NOJNI: & $Y$ & NI:C; \\
\hline & M1:2153 s9 & ()I) & AC $C^{\circ}$ & $5 / \mathrm{W} / \mathrm{L}$ & NC JNI: & $Y$ & $N / A$ \\
\hline 17 & MI:2ISo s" & (isw & St if & $(x) / W / M$ & (1) AYS & $N$ & $N / A$ \\
\hline
\end{tabular}

Ni:cicosilonit:

NI)

NI) ?

Ni)

NI)!

$\mathrm{N} / \mathrm{A}$

NiA

उC ARIBAMAVIPINI:

$\mathrm{N} / \mathrm{A}$

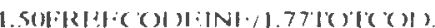
(1.).MIMI:PI'RIIINI:III)

NiA

$N / A$

NI)

X.7I) OXIIIN 


\section{APPENDIX B.}

CAUSE OF DEATH MASTER LIST

$\begin{array}{ll}\text { ACC } & \text { ACCIDENTAL } \\ \text { ALC } & \text { ALCOHOLISM (ACUTE/CHRONIC) } \\ \text { ANEU } & \text { ANEURYSM } \\ \text { ASHD } & \text { ARTERIOSCLEROTIC HEART DISEASE } \\ \text { ASPX } & \text { ASPHYXIA } \\ \text { ASTM } & \text { ASTHMA } \\ \text { CCT } & \text { CRANIO-CEREBRAL TRAUMA } \\ \text { COI } & \text { CARBON MONOXIDE INTOXICATION } \\ \text { COPD } & \text { CHRONIC OCCLUDED PULMONARY DISEASE } \\ \text { DIS } & \text { DISEASE } \\ \text { DMVA } & \text { DRIVER/MOTOR VEHICLE ACCIDENT } \\ \text { DROW } & \text { DROWNING } \\ \text { ELECT } & \text { ELECTROCUTION } \\ \text { EXSG } & \text { EXSANGUINATION } \\ \text { GSW } & \text { GUN SHOT WOUND } \\ \text { HGSW } & \text { HOMICIDE GUN SHOT WOUND } \\ \text { HOM } & \text { HOMICIDE } \\ \text { IDDM } & \text { INSULIN DEPENDENT DIABETES MELLITUS } \\ \text { IVDA } & \text { INTRAVENOUS DRUG ABUSE } \\ \text { LIV } & \text { LIVER NECROSIS } \\ \text { MVA } & \text { MOTOR VEHICLE ACCIDENT } \\ \text { NAT } & \text { NATURAL DEATH } \\ \text { OD } & \text { OVERDOSE } \\ \text { PEND } & \text { PENDING } \\ \text { RHD } & \text { RHEUMATIC HEART DISEASE } \\ \text { SGSW } & \text { SUICIDE/GUN SHOT WOUND } \\ \text { SIDS } & \text { SUDDEN INFANT DEATH SYNDROME } \\ \text { SUDS } & \text { SUDDEN UNEXPLAINED DEATH SYNDROME } \\ \text { SUIC } & \text { SUICIDE } \\ \text { SURG } & \text { SURGICAL MISADVENTURE } \\ & \end{array}$




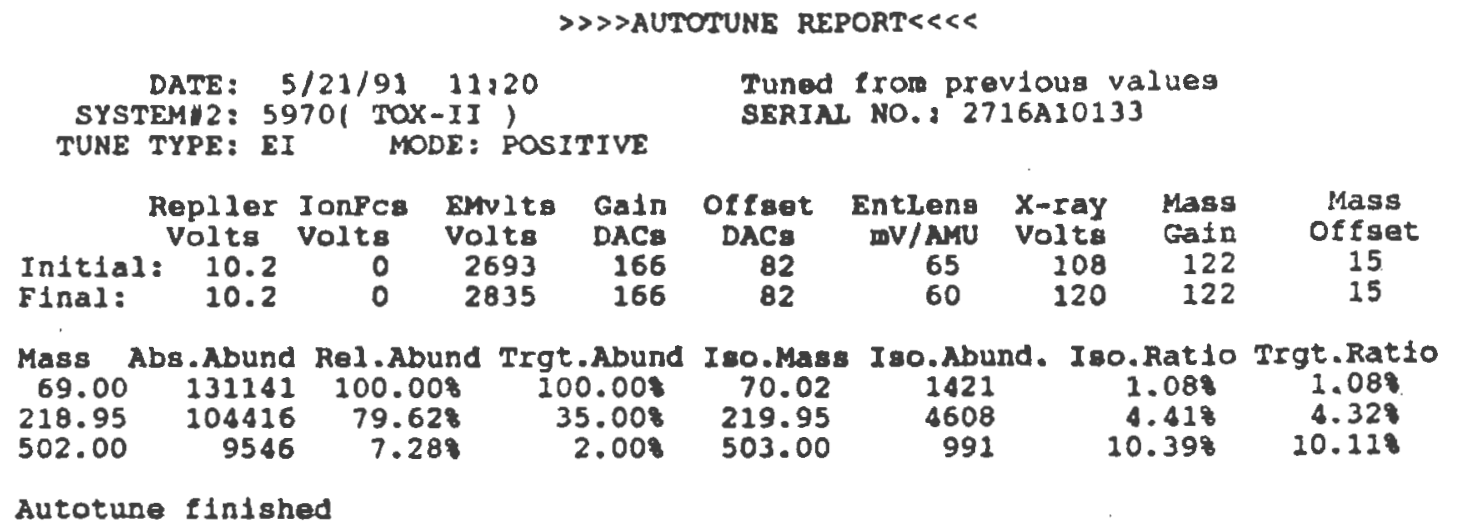

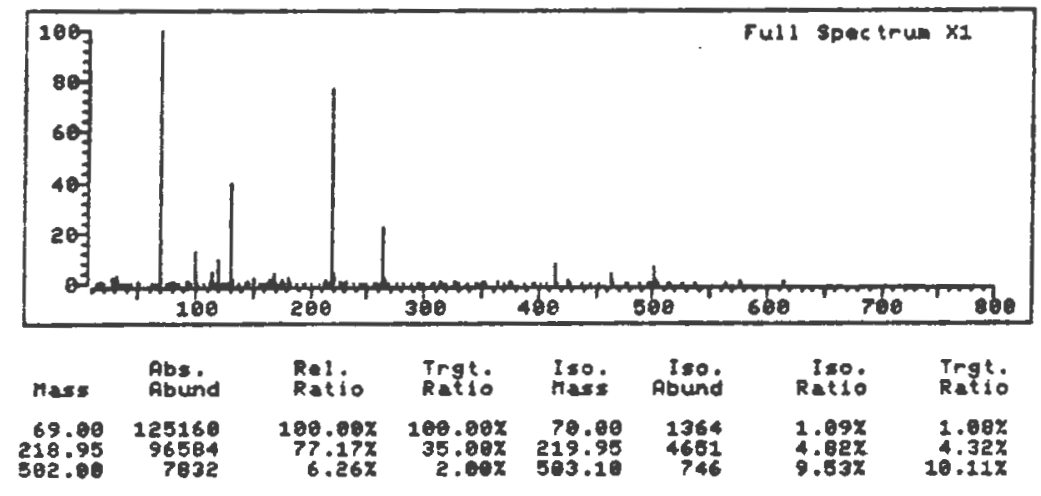

APPENDIX C. 
64.

\section{APPENDIX D.}

\section{COCAINE/BENZOYLECGONINE PROCEDURE ${ }^{1}$}

1) ADD TO A CLEAN TEST TUBE: INTERNAL STANDARD (500 NG D3-COCAINE)

(500 NG D3-BENZOYLECGONINE)

1 ML OF SPECIMEN (BLOOD, URINE, GASTRIC, ETC)

2 ML PHOSPHATE BUFFER PH 7.0

2) MIX AND ADD TO EXTRELUT EXTRACTION COLUMN. LET ADSORB 4-5 MINS

3) ELUTE INTO A DISPOSABLE 15 ML CENTRIFUGE TUBE WITH TWO 8 ML ALIQUOTS OF 9:1 $\mathrm{CHCL}_{3} /$ ISOP

4) SPLIT SAMPLE AND EVAPORATE TO DRYNESS ON N-EVAP

5) DERIVATIZE BENZOYLECGONINE IN ONE TUBE TO N-PROPYL COCAINE BY BOILING OVER AN OPEN FLAME WITH N,N DIMETHYLFORMAMIDE DI-N-PROPYL ACETAL FOR 30 SECONDS

6) $\mathrm{ADD}$ 1ML $\mathrm{H}_{2} \mathrm{SO}_{4} \mathrm{TO}$ TUBE.

7) CLEANUP STEP. ADD 3 ML OF TOLUENE:HEPTANE:ISOAMYL ALCOHOL (76:20:4) TO AQUEOUS AND VORTEX DISCARD ORGANIC.

8) NEUTRALIZE AQUEOUS WITH 2 ML SODIUM CARBONATE BUFFER PH 9.0

9) EXTRACT WITH 3 ML OF TOLUENE: HEPTANE: ISOAMYL ALCOHOL. TRANSFER ORGANIC PHASE TO A CLEAN CONICAL CENTRIFUGE TUBE AND EVAPORATE ON N-EVAP.

10) RECONSTITUTE WITH 100 UL CHCL 3 AND TRANSFER TO AN AUTOSAMPLER VIAL FOR MASS SPECTRAL ANALYSIS.

\section{MASS SPECTROMETER PARAMETERS}

METHOD- COCBEN : : D5

INJECTION VOLUME- 3 ul

IDFILE- IDBEC

FMGR TR FILE- SIMFX::D5

1 ADAPTED FROM "A METHOD FOR THE SIMULTANEOUS DETERMINATION OF COCAINE, BENZOYLECGONINE AND ECGONINE METHYL ESTER IN BLOOD AND URINE USING GC/EIMS WITH DERIVATIZATION TO PRODUCE HIGH MASS MOLECULAR IONS" ISENSCHMID ET AL., JOUR. OF ANAL. TOX.12:9-10;1988 
Correlation coefficient:

$$
\begin{aligned}
& r=\frac{s_{x y}}{s_{x x}} \sqrt{s_{y y}} \\
& \text { where } s_{x y}=\sum(x-\bar{x})(y-\bar{y}) \\
& s_{x x}=\sum(x-\bar{x})^{2}, s_{y y}=\sum(y-\bar{y})^{2}
\end{aligned}
$$

The quantities $s_{x x}$ and $s_{y y}$ are the sums of squared deviations of the $x$ observations, and the $y$ observations, respectively, $S_{x y}$ is the sum of cross products of the $x$ deviations and the y deviations.

N.B.: An observed correlation between two variables may be spurious. That is, it may be caused by the influence of a third variable.

Standard Deviation:

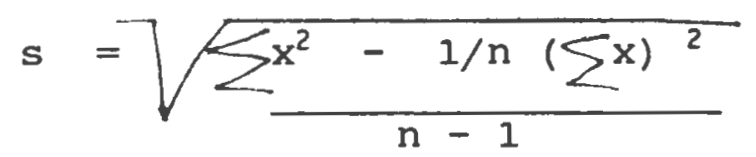

Coefficient of Variation:

$$
\mathrm{CV} \% \frac{\mathrm{s}}{\overline{\mathrm{x}}}
$$


66.

\section{BIBLIOGRAPHY}

Abbott Laboratories. $\mathrm{AD}_{\mathrm{x}}$ System operator's Guide: Cocaine Metabolites. Abbott Laboratories Diagnostics Division (revised $4 / 90)$.

Ambre, J., "The Urinary Excretion of Cocaine and Metabolites in Humans: A Kinetic Analysis of Published Data." Journal of Analytical Toxicology, 9: 241-245, 1985 .

Ambre, J., Ruo, T., Nelson, J., and Belknap, S., "Urinary Excretion of Cocaine, Benzoylecgonine, Ecgonine Methyl Ester in Humans." Journal of Analytical Toxicology, 12: 301-306, 1988 .

Baselt, R.A. and Cravey, R.H., ..: Disposition of Toxic Drugs and Chemicals in Man, $3 r d$ ed., Year Book Medical, Chicago, 208-213, 1989.

Baselt, R., "The stability of Cocaine in Biological Fluids." Journal of Chromatography, 268: 502-503, 1983 .

Beno, J.M. and Kriewall, S., "Postmortem Elevation of Cocaine Levels in Vitreous Humor", presented at the 1989 meeting of the Society of Forensic Toxicologists, Chicago, IL., October, 1989 .

Browne, S.P. , Moore, C.M., Scheurer, J., Tebbet, I.R., and Logan, B.K., "A Rapid Method for the Determination of Cocaine in Brain Tissue." Journal of Forensic Sciences, 36: 1662$1665,1991$.

Caplan, Y.H., Levine, B., and Goldberger, B., "Fluorescence Polarization Immunoassay for Screening for Amphetamine and Methamphetamine in Urine." Clinical Chemistry, 33: 1200-1202, 1987.

Caplan, Y.H. and Levine, B., "Evaluation of the Abbott FPIA Benzodiazepine Assay using the ADx Analyzer." Clinical Chemistry, 34: 1271, 1988.

Caplan, Y.H. and Levine, B., "Application of the Abbott TDX Lidocaine, Phenytoin, and Phenobarbital Assays to Postmortem Blood Specimens." Journal of Analytical Toxicology, 12: 265$267,1988$.

Caplan, Y.H. and Levine, B., "Vitreous Humor in the Evaluation of Postmortem Blood Ethanol Concentrations." Journal of Analytical Toxicology, 14:305-307, 1990.

Chinn, D.M., Crouch, D.J., and Peat, M.A., "Gas Chromatography - Chemical Ionization Mass spectrometry of cocaine and its 
Metabolites in Biological Fluids." Journal of Analytical Toxicology, 4 : $37-42,1980$.

Coe, J.I. and Apple, F.S., "Variations in Vitreous Humor Chemical Values as a Result of Instrumentation." Journal of Forensic Sciences, 30: 828-835, 1985.

Coe, J.I. and Sherman, R.E., "Comparative study of Postmortem Vitreous Humor and Blood Alcohol." Journal of Forensic Sciences, 15, 185-190, 1970.

Cone, E.J., Menchen, S.L.l, and Mitchell, J., "Validity Testing of the TDx Cocaine Metabolite Assay with Human specimens obtained After Intravenous Cocaine Administration." Forensic Science International, 37: 266-275, 1988.

Devgun, M.S. and Dunbar, J.A., "Biochemical Investigation of Vitreous: Applications in Forensic Medicine, Especially in Relation to Alcohol." Forensic Science International, 31: 27$34,1986$.

Evans, M.A. and Morarity, T., "Analysis of Cocaine and Cocaine Metabolites by High Pressure Liquid Chromatography." Journal of Analytical Toxicology, 4: 19-22, 1980.

Evenson, M.A. and Engstrand, D.A., "A SepPak HPLC Method for Tricyclic Antidepressant Drugs in Human Vitreous Humor." Journal of Analytical Toxicology, 13: (6), 322-325, 1984.

Felby, S. Pharm, B., and olsen, J., "Comparative studies of Postmortem Barbiturates and Meprobamate in Vitreous Humor, Blood, and Liver." Journal of Forensic Sciences, 14: (4): 507-514, 1969 .

Foltz, R.L. and Yang, J.Y., "Cocaine Metabolism in Man, Identification of Four Previously Unreported Metabolites in Human Urine." Journal of Analytical Toxicology, 14: 201-205, 1990.

Griesmer, E.C., Liu, Y., Budd, R.D., Raftogiamis, L., and Noguchi, T., "The Determination of Cocaine and its Major Metabolite, Benzoylecgonine, in Postmortem Fluids and Tissues by Computerized Gas Chromatography/Mass Spectrometry. " Journal of Forensic Sciences, 28: 894-900, 1983.

Hearn, W.L., "The Application of Fluorescence Polariza-tion (Abbott TDx) Lidocaine Assay in Forensic Toxicology." In Proceedings of the $24^{\text {th }}$ International Meeting, The International Association of Forensic Toxicologists, Banff, Alberta, Canada, 344-351, 1987.

Hearn, W.L., Keran, E.E., Wei, H., and Hime, G., "SiteDependent Postmortem Changes in Blood Cocaine Concentrations." Journal of Forensic Sciences, 36: (3): 673-684, 1991. 
Inaba, T., stewart, D.J. and Kalow, W., "Metabolism of Cocaine in Man." clinical Pharmacology and Therapeutics, 23: 547552,1978 .

Isenschmid, D.S. Levine, B.S. and Caplan, Y.H., "A Method for the Simultaneous Determination of Cocaine, Benzoylecgonine, and Ecgonine Methyl Ester in Blood and Urine Using GC/EIMS with Derivatization to Produce High Mass Molecular Ions." Journal of Analytical Toxicology, 12: 242-245, 1988.

Isenschmid, D.S., Levine, B.S. and Caplan, Y.H., "A Comprehensive study of the stability of Cocaine and its Metabolites." Journal of Analytical Toxicology, 13: (5), 250-256, 1989.

Jolley, M.E., "Fluorescence Polarization Immunoassay for the Determination of Therapeutic Drug Levels in Human Plasma." Journal of Analytical Toxicology, $\underline{5}$ : $236-240,1981$.

Jones, G.R. and Pounder, D.J., "Site Dependence of Drug Concentrations in Postmortem Blood - A Case Study." Journal of Analytical Toxicology, 11: (5), 184-190, 1987.

Logan, B.K. and Stafford, D.T., "Direct Analysis of Anticonvulsant Drugs in Vitreous Humor by HPLC using a column Switching Technique." Forensic Science International, 41: (12), 125-134, 1989 .

Manhoff, D.T., Hood, I., Caputo, F., Perry, J., Rosen, S., Mirchandani, H.G., "Cocaine in Decomposed Human Remains." Journal of Forensic Sciences, 36: 1732-1735, 1991.

Marker, E.K., Krasswelt, W.G., and Mueggler, P.A., "Evaluation of the Abbott TDx for Determination of Phenobarbital in Forensic Blood Specimens." Journal of Analytical Toxicology, 11: 257-259, 1987.

Martz, R., Donnelly, B., Fetterolf, D., Lasswell, L., Hime, G.W., and Hearn, W.L., "The Use of Hair Analysis to Document a Cocaine overdose following a sustained Survival Period Before Death." Journal of Analytical Toxicology, 15: 279-281, 1991.

Matsubara, K., Maseda, C., and Fukui, V., "Quantitation of Cocaine, Benzoylecgonine and Ecgonine Methyl Ester by GC-CISIM after Extrelut Extraction." Forensic Science International, 26: 181-192, 1984 .

Matsubara, K., Kagawa, M., and Fukui, Y., "In Vivo and In Vitro studies on Cocaine Metabolism: Ecgonine Methyl Ester as a Major Metabolite of Cocaine." Forensic Science International, 26: 169-180, 1984 .

Mccord, C.E. and McCutcheon, J.R., "Preliminary Evaluation of 
the Abbott TDx for Benzoylecgonine and opiate screening in Whole Blood." Journal of Analytical Toxicology, 12: 295-297, 1988 .

Mirchandani, H.C., Mirchandani, I.H., Hellman, F., EnglishRider, R., Rosen, S., Laposata, E.A., "Passive Inhalation of Free-Base Cocaine ("Crack') smoke by Infants." Archives of Pathology and Laboratory Medicine, 115: 494-498, 1991.

Mittleman, R.E. and Wetli, C.V., "Death Caused by Recreational Cocaine Use." Journal of the American Medical Association, 252: 1889-1893, 1984 .

Poklis, A., Mackell M.A., Graham, M., "Disposition of Cocaine in Fatal Poisoning in Man." Journal of Analytical Toxicology, g: $227-229,1985$.

Poklis, A., "Evaluation of TDx Cocaine Metabolite Assay." Journal of Analytical Toxicology, 11: 228-230, 1987.

Rohrig, T.P., Rundle, D.A., and Leifer, W.N., "Fatality Resulting from Metoprolol overdose." Journal of Analytical Toxicology, 11: (5), 231-232, 1987.

Saferstein, R. : Criminalistics, An Introduction to Forensic Science. Englewood cliffs, N.J.: Prentice-Hall, Inc., 247-274, 1990 .

Smart, R.G. and Anglin, L., "Do we know the Lethal Dose of Cocaine?" Journal of Forensic Sciences, 8: 303-310, 1987.

Sorensen, P.N., "The Penetration of Quinine, Salicylic Acid, Barbital, and Lithium Across the Vitreous Barrier of the Rabbit Eye." Acta Pharmacologica et Toxicologica, 29: 194208, 1971.

Sparks, D.L., Oeltgen, P.R., Kryscio, R.J., and Hunsaker, J.C., "Comparison of Chemical Methods for Determining Postmortem Interval." Journal of Forensic Sciences, 34: (1), 197-206, 1989 .

Spiehler, V.R. and Reed, D., "Brain Concentrations of Cocaine and Benzoylecgonine in Fatal Cases." Journal of Forensic Sciences, 30: 1003-1011, 1985.

Sturner, W.Q. and Coumbis, R.J., "The Quantitation of Ethyl Alcohol in Vitreous Humor and Blood by Gas Chromatography." American Journal of Clinical Pathology, 46: 249-251, 1966.

Sturner, W.Q. and Garriott, J.C., "Comparative Toxicology in Vitreous Humor and Blood." Journal of Forensic Sciences, $\underline{6}$ : (4), 31-35, 1975 .

Sturner, W.Q., Sweeney, K.S., Callery, R.T., and Haley, N.R., 
"Cocaine Babies: The Scourge of the 90's." Journal of Forensic Sciences, 36: 34-39, 1991.

Sweeney, K.S. Personal communication. Presentation for the National Association of Medical Examiners (NAME) meeting, Waterville, Maine, August, 1991.

Tebbett, I.R. and McCartney, Q.W., "A Rapid Method for the Extraction of Cocaine and Benzoylecgonine from Body Fluids." Forensic Science International, 39: 289-291, 1988 .

Welti, C.V., Fishbain, D.A., "Cocaine-Induced Psychosis and Sudden Death in Recreational Cocaine Users." Journal of Forensic Sciences, 30: 873-880, 1985 .

Welti, C.V. and Wright, R.K., "Death Caused by Recreational Use." Journal of the American Medical Association., 241: $2519-2522,1979$.

Ziminski, K.R., Wemyss, C.T., Bidanset, J.H., Manning, T.J., and Lukash, L., "Comparative study of Postmortem Barbiturates, Methadone, and Morphine in Vitreous Humor, Blood, and Tissue." Journal of Forensic Sciences, 29: (3), 903-909, 1984 . 